\title{
ON THE PROBABILITY OF THE CREATION OF THE IBN \\ TAYMIYYA SCHOOL OF OTTOMAN THOUGHT \\ VIA BIRGIWĪ MEḤMED EFENDĪ \\ - A Critical Approach -
}

\author{
Âdem Arikan \\ Istanbul University, Istanbul-Turkey \\ E-mail: arikana@istanbul.edu.tr
}

\begin{abstract}
Ottoman religious thought is divided into two essential schools named after Fakhr al-Dīn al-Rāzì and Ibn Taymiyya. The Fakhr al-Dīn al-Rāzī School is identified with Māturīdism, whereas Ottoman scholar Birgiwī Mehmed Efendī (929-981/1523-1573) is considered a disciple of the Ibn Taymiyya School. Birgiwi's madhhab is often described as Salafī, Ḥanbalī, Ash'arī, or Māturīìi. This study assesses such claims using evidence from the sources whose attribution to Birgiwi is indisputable. An analysis of Birgiwi's works clearly shows that he is a member of the Māturīdī School. Nevertheless, the study reveals the necessity of reviewing certain classifications, denominations, and generalizations. Based on Birgiwì's extant works, this paper makes several objections to his being considered a representative or member of the Ibn Taymiyya School and demonstrates that Birgiwi is completely aligned with Māturīdī with regard to theological issues.
\end{abstract}

Key Words: Birgiwī Meḥmed Efendī, Ibn Taymiyya, Salafism, Māturīdism, Ottoman religious thought 


\section{Introduction}

The Ottoman Empire existed for centuries and covered a vast geographical area. Studies on this era adopt numerous approaches and use a variety of definitions and classifications. According to one of these classifications, Ottoman religious thought is principally shaped by two schools: the 'Fakhr al-Dīn al-Rāzī School' and the 'Ibn Taymiyya School.' According to this classification, Birgiwī Mehmed Efendi (929-981/1523-1573) is a representative of the Ibn Taymiyya School. ${ }^{1}$

The influence of Ibn Taymiyya in Wahhābī circles made his other circles of influence the subject of scholarly research. Prior to Wahhābism, Ibn Taymiyya's views influenced certain scholarly circles in the vast Ottoman territory. In the history of Islamic sects, Salafism comes to mind as the first to incorporate the opinions of Ibn Taymiyya. According to certain academics, Salafism, however, is an ideology rather than a madhbab. ${ }^{2}$ The acceptance of Salafism as a madhbab is unwelcome ( $\operatorname{bid}^{\prime} a$ ) to those who are tied to the Salaf. ${ }^{3}$

By consulting Birgiwī's extant works, this study intends to reveal possible objections to his positioning within the Ibn Taymiyya School.

\section{Birgiwī and the Ibn Taymiyya School}

Birgiwī was born in Balıkesir in 929/1523. ${ }^{4}$ His father was mudarris Pīr 'Alī who provided Birgiwī with his initial education. ${ }^{5}$ Birgiwī later

1 Ahmet Yaşar Ocak, Yeniçağlar Anadolu'sunda İslam'in Ayak İzleri: Osmanl Dönemi, Makaleler-Araştırmalar (Istanbul: Kitap Yayınevi, 2011), 178 (hereafter cited as Osmanh Dönemi).

2 Mehmet Hayri Kırbaşoğlu, "Maziden Atiye Selefî̀ Düşüncenin Anatomisi," İslâmiyât 10/1 (2007), 142.

3 Muhammad Sa`̄id Ramaḍān al-Būțī, al-Salafiyya: marhala zamaniyya mubāraka lā madhhab Islāmī (8 ${ }^{\text {th }}$ edn., Damascus: Dār al-Fikr, 2006), $219 \mathrm{ff}$.

4 In Birgiwī's words, "I was born on the tenth day of Jamādī al-awwal in the year nine hundred twenty-nine (929)." See Muḥammad ibn Pīr 'Alī al-Birgiwì, Vasiyyet-nâme: Dil Incelemesi, Metin, Sözlük, Ekler Indeksi ve Tipkıbasim (ed. Musa Duman; Istanbul: Risale Yayınları, 2000), 122 (hereafter cited as Vasiyyetnâme).

5 Abū Muḥammad Muștafā ibn Ḥusayn ibn Sinān al-Janābī, al-'`Aylam al-zākhir fì ahwāl al-awā'il wa-l-awākhir [also known as Tārīkh al-Janābì] (MS Istanbul, 
left for Istanbul and attended courses taught by Akhī-zāda Meḥmed Efendī (d. 974/1563) and Qāẹī'‘askar 'Abd al-Rahmān Efendī (d. 983/1575). He was also a follower of 'Abd Allāh al-Qaramānī (d. 972/1564-5), the Bayrāmī sheikh. At the recommendation of his sheikh, he resumed his courses and irshād activities. He was subsequently appointed mudarris of Dār al-Hadìth, which was built in Birgi at the behest of 'Ațā' Allāh Efendī (d. 979/1571), the mentor of Sultan Selìm II (1566-1574). ${ }^{6}$ He spent the remainder of his life in Birgi, pursuing educational and writing activities. He became known by the name Birgiwī (from Birgi). In the twilight of his life, Birgiwi returned to Istanbul to advise Soqollu Mehmed Pāshā (d. 987/1579), the Grand Vizier. Birgiwī passed away in 981/1573 and was interred in Birgi. ${ }^{7}$

Birgiwī's views remained influential for many years. According to classical references, Birgiwi had many followers during the Ottoman era. Terzioğlu found the expression "khulafā" of Birgiwī" among fatwās by As'ad Efendī (Sheikh al-Islām between 1615-1622 and 1623-1625) and also "Birgiwīs" in a treatise written by one Hājīi Ahmad in 1056/1646-1647. ${ }^{8}$

Nuruosmaniye Library, no: 3100), 427a. Muhammad ibn Bahā' al-Dīn (d. 953/1546), the cousin of Birgiwīe, consulted Pīr 'Alī before writing a commentary on al-Fiqh al-akbar by al-Imām Abū Hanīfa; see Ḥājī Khalīfa Muṣțaā ibn 'Abd Allāh Kātib Chalabī (as Kâtip Çelebi), Mîzânü'l-Hakk fî̀ ihtiyâri'l-ehakk [=Mìzān al-ḥaqq fì ikhtiyār al-aḥaqq] (translated into Turkish Orhan Şaik Gökyay and Süleyman Uludağ; Istanbul: Kabalc1 Yayınevi, 2008), 51, 179, 297.

6 For a description of Birgiwī's educational activities at the madrasa, see Huriye Mart1, Osmanli'da Bir Dâru'l-Hadis Şeybi: Birgivî Mebmed Efendi (Istanbul: Dârulhadis, 2008), $59 \mathrm{ff}$.

7 'Alī ibn Bālī, al-'Tqd al-manzūm fì dhikr afādil al-Rūm [as an annex to alShaqā’iq al-Nu'māniyya by Ṭāshkuprī-zāda] (Beirut: Dār al-Kitāb al-'Arabī, 1975), 436-437; Naw'ī-zāda 'Ațā')ī, Hadā'iq al-ḥaqā'iq fì takmilat al-Shaqā'iq (Istanbul: Çağrı Yayınları, 1989), II, 179-181; For further information and sources about the life of Birgiwī, see Kasım Kufrevî, "Birgewī," in: Encyclopaedia of Islam Second Edition (eds. P. Bearman, Th. Bianquis, C.E. Bosworth, E. van Donzel, and W.P. Heinrichs; accessed June 16, 2015), http://dx.doi.org/10.1163/15733912_islam_SIM_1434.

8 Derin Terzioğlu, Sufi and Dissident in the Ottoman Empire: Niyāzī-i Mișrī, 16181694 (PhD dissertation; Cambridge, MA: Harvard University, 1999), 200, 202; id., "Sunna-minded sufi preachers in service of the ottoman state: the nașịatnāme 
Ottoman religious thought is generally categorized into the 'Fakhr al-Dīn al-Rāzì School' and the 'Ibn Taymiyya School.' Within this division, Birgiwi is typically positioned as a follower of the Ibn Taymiyya School:

Ottoman scholars preferred two regions, namely, the Middle East and Central Asia, for education in the religious sciences. (...) Whoever studied and was specialized in these regions essentially brought two theological schools into the Ottoman lands. The first is the Fakhr alDīn al-Rāzì (or briefly Fakhr al-Rāzī) school, preferred by the Ottoman central government during the establishment of the Ottoman religious bureaucracy; and the second is the Ibn Taymiyya school, which was initiated as a reaction to the former in the $16^{\text {th }}$ century.

Based on reason ('aql) and ideas $\left(r a^{\prime} y\right)$, the Fakhr al-Rāzī School was strongly represented by prominent scholars during the post-Ghazāli era (d. 1111) from the $12^{\text {th }}$ to the late $14^{\text {th }}$ century, including Najm alDīn 'Umar al-Nasafĩ (d. 537/1142), Abū l-Qāsim Mạ̣mūd alZamakhsharī (d. 538/1144), Burhān al-Dīn al-Marghīnānī (d. 593/1197), Fakhr al-Dīn al-Rāzì (d. 606/1209), Nașīr al-Dīn al-Ṭūsī (d. 672/1274), Qāđ̣ī al-Bayḍāwī (d. 685/1286), 'Aḍud al-Dīn al-İjī (d. 756/1335) Quṭb al-Dīn al-Rāzī (d. 766/1364), Sa`d al-Dīn al-Taftāzānī (d. 792/1390), and Sayyid Sharīf al-Jurjānī (d. 816/1413). ${ }^{9}$

Numerous studies repeat these views about the foregoing classification. Māturīdism is described under the heading of "the Fakhr al-Rāzì School and followers," indicating that Māturīdism replaced the Rāzī School. The Rāzī School is therefore identified with Māturīdism, and the same scholars are mentioned as representatives of both:

Māturīdism, one of the two major faith schools in Sunnī Islam (Ash'arism is the other), was founded by Muhammad Abū Manșūr al-

of Hasan addressed to Murad IV," Archivum Ottomanicum 27 (2010), 255 (The records by Terzioğlu about the manuscripts are as follows: As`ad Efendī, Fatāwāyi Muntakhab (MS Istanbul: Süleymaniye Library, Kasidecizade, no: 277), 1b-6b, 46b; Hājīi Aḥmad, Risāla-i 'aj̄̄ba (MS Istanbul: Topkapı Palace Museum Library, Bağdat Elyazmalar1, no: 404), 96b-98b.

9 Ocak, "Ottoman Intellectual Life in the Classical Period,” in H. C. Güzel, K. Çiçek, and S. Koca (eds.), The Turks (Ankara: Yeni Türkiye Yayınları, 2002), III, 749-750; Ocak, "Religious Sciences and the Ulema," in Halil İnalcık and Günsel Renda (eds.), Ottoman Civilization (translated into English by Ellen Yazar and Priscilla Mary Işın; Ankara: Ministry of Culture, 2003), I, 260-261. 
Māturīdī (d. 333/944) in Samarqand. Based on 'aql and $r a^{\prime} y$, the school achieved great progress thanks to efforts by scholars educated in the Transoxiana and Khwārizm, such as (...) 'Umar al-Nasafī, alZamakhsharī, (...), Fakhr al-Dīn al-Rāzì, and Nașīr al-Dīn al-Ṭūsī, (...) who were notable names in the muta'akbkbirūn tradition. ${ }^{10}$

Fakhr al-Dīn al-Rāzī's criticisms of Māturīdism during his discussions with Māturīdī scholar Nūr al-Dīn al-Ṣābūnī (d. 580/1184) can be read today in al-Rāzī's own works. ${ }^{11}$ Therefore, it could be possible to oppose against this categorization through al-Rāzì's own writings. Other sources and studies about the Rāzì School and its disciples or followers also mention the names of certain scholars within the context of restrictions to the definitions of terms such as wisdom (bikma), logic (mantiq), and investigation (tabquiq). ${ }^{12}$ In the abovementioned categorization, these scholars are known for "concentrating on 'aql and ra'y;" therefore, these features must be taken into account when positioning them within the Rāzì/Māturīìi School. ${ }^{13}$ Nevertheless, descriptions about Birgiwī, which place him at the center of the opposite side (the Ibn Taymiyya School), prove that the classification was also based on madhbab identities:

Thus, as early as his lifetime, Birgiwī gave birth to a second and purist Sunnī approach as an alternative to the pragmatic Sunnī theology of the Ottoman central government; therefore, even though he is actually a Hanafī, it would not be incorrect to associate him with Ibn Taymiyya, or even the Hanbali School. ${ }^{14}$

10 Ocak, Osmanl Dönemi, 175; id., "Religious Sciences and the Ulema," 261; id., "al-Hayāt al-dīniyya wa-l-fikriyya," in Ekmeleddin İhsanoğlu (ed.), al-Dawla al'Uthmāniyya: tārīkh wa-ḥaḍarra (translated into Arabic by Ṣālị̣ Ṣa'dāwī; Istanbul: IRCICA, 1999), II, 247.

11 Abū 'Abd Allāh Fakhr al-Dīn Muḥammad ibn 'Umar al-Rāzī, Munāzarāt Fakhr alDìn al-Rāzī fì bilād Māwarāò al-nahr (ed. Fatḥ Allāh Khulayf; Beirut: Dār alMashriq, 1966), 53, and 14, 17, 23.

12 For sources, studies and other details about the Rāzī School, see Mustakim Arıcı, "İslâm Düşüncesinde Fahreddin er-Razi Ekolü," in Ömer Türker and Osman Demir (eds.), Fabreddin Râzî (Istanbul: İSAM Yayınları, 2013), 167-202.

13 Indeed, in his discussion of Birgiwī's attitude toward bid'a, Ocak says, "Even though he was a Hanafī, he followed the Ibn Taymiyya School in this respect," Osmanı Dönemi, 222.

14 Ocak, Osmanl Dönemi, 179-180; id., "al-Hayāt al-dīniyya wa-l-fikriyya," 251; id., "Religious Sciences and the Ulema," 263. For similar opinions, see Hulusi Lekesiz, 
Birgiwī himself states his affiliation with the Hanafī School. ${ }^{15} \mathrm{He}$ also mentions the names and views of al-Zamakhsharī, Qādī alBayḍāwī, (Fakhr al-Dīn) al-Rāzīi, and Abū Manșūr ${ }^{16}$ (al-Māturīdī) who all are accepted to be main figures of the other school. ${ }^{17}$ Nevertheless, Birgiwi never mentions the name of Ibn Taymiyya in any of his works. Birgiwī's disagreement with contemporaneous scholars on some issues ${ }^{18}$ does not change the fact that he was Hanafi and Māturīdī. Birgiwī often refers to Hanafī books on jurisprudence and fatwā to justify his views. It is well-known that Māturīdism "is not represented in the same manner in every region." ${ }^{19}$ It would therefore be inaccurate to identify the various opinions of Birgiwi exclusively with Hanbalism, the Ibn Taymiyya School, and Salafism.

Ahl al-sunna is often divided into three main subcategories: Salafiyya (Athariyya, Hanābila), Māturīdiyya, and Ash'ariyya. This traditional three-part classification, which includes Hanbalī scholars, ${ }^{20}$

"Osmanlı İlmi Zihniyeti: Teşekkülü, Gelişmesi ve Çözülmesi Üzerine Bir Tahlil Denemesi," Türk Yurdu 11/49 (1991), 24, 25; Fahri Unan, "Dinde Tasfiyecilik Yahut Osmanlı Sünnîliğine Sünnî Muhâlefet: Birgivî Mehmed Efendi," Türk Yurdu 36/382 (1990), 34-35.

15 If asked "to which madhhab do you belong in deeds?" tell them "Imām Abū Haniffa," but never say "Abū Haniffa's madhbab is right and the others are deviant." Vasiyyet-nâme, 107. See also Birgiwī, al-Ṭariqa al-Muhammadiyya wa-l-sīra alAḥmadiyya (ed. Muḥammad Ḥusnī Mușțafā; Aleppo: Dār al-Qalam al-'Arabī, 2002), 399.

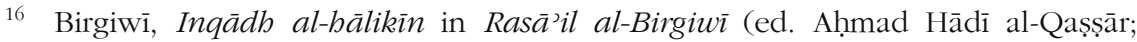
Beirut: Dār al-Kutub al-'Ilmiyya, 2011), 73.

17 Birgiwī, al-Ṭarīqa, 201; id., Inqādh al-hālikīn, 54.

18 The Cash waqf, one of the subjects Birgiwī expresses a dissenting opinion, had already been discussed by the Ottoman scholars who preceded him. Abū Hanīfa and his followers expressed various opinions about these foundations. For the scholars who participated in these discussions prior to Birgiwī, see Tahsin Özcan, Osmanlı Para Vakıfları (Ankara: Türk Tarih Kurumu, 2003), 28 ff.

19 Mehmet Kalayc1, Tarihsel Süreçte Eşarilik-Maturidilik İlişkisi (Ankara: Ankara Okulu Yayınları, 2013), 129.

20 'Abd al-Bāqī ibn 'Abd al-Bāqī Ibn Faqīh Fiṣṣa al-Mawāhibī al-Ḥanbalī, al-'Ayn wa-l-athar fì 'aqā'id abl al-athar (ed. 'Ișām Rawwās Qal'ajīi Damascus: Dār alMa'mūn li-1-Turāth, 1987), 53; Abū 1-'Awn Shams al-Dīn Muhammad ibn Aḥmad ibn Sālim al-Saffārīnī al-Ḥanbalī, Lawāmi al-anwār al-bahiyya wa-sawātị alasrār al-athariyya li-sharh al-Durra al-mudiyya fì 'aqd al-firqa al-mardiyya (2 ${ }^{\text {nd }}$ edn., Damascus: Mu’assasat al-Khāfiqīn wa-Maktabatuhā, 1982), I, 73. 
is generally accepted despite certain variations. ${ }^{21}$ Nevertheless, Wahhābīs, who also identify with the Hanbali School, claim that Māturīdiyya and Ash cariyya are not sects that will attain salvation (alfirqa al-nājiya). According to this exclusivist Wahhābī view, "Ahl alsunna is but a sect," and Ibn Taymiyya is the one who declared the faith of Ahl al-sunna. ${ }^{22}$ As we will discuss later, some certain researchers who adopt Wahhābī views conclude that Birgiwī adhered to the Māturīdiyya and criticize him for his views showing that they do not agree with Ibn Taymiyya's ones.

\section{Allegations of References to Ibn Taymiyya in Birgiwi's Works}

Birgiwi incorporates the views of many scholars into his works. For example, Birgiwì's al-Tariqa includes many references to alGhazālī. ${ }^{23}$ Relevant studies have identified similarities between his views and those of al-Ghazāli in Ihyya ${ }^{2}{ }^{24}$ We also know ${ }^{25}$ that Birgiwi did express dissidence with al-Ghazālī when it occurs. ${ }^{26}$ Birgiwī also frequently consults many sources that discuss similar themes, such as those by Hanafī scholar Abū 1-Layth al-Samarqandī (d. 373/983). ${ }^{27}$

21 Sa`d al-Dīn Mas'ūd ibn 'Umar ibn 'Abd Allāh al-Taftāzānī, Sharḥ al-Maqāṣid (ed. 'Abd al-Raḥmān 'Umayra; $2^{\text {nd }}$ edn., Beirut: 'Ālam al-Kutub, 1998), V, 231; Abū Sa⿳̄̄d Muḥammad ibn Mușțafā ibn 'Uthmān al-Khādimī, al-Barīqa alMaḥmūdiyya fì sharh al-Ṭarīa al-Muḥammadiyya (Istanbul: Shirkat-i Șahāfiyya-i 'Uthmāniyya, 1316), I, 201; Abū l-Fayḍ Muḥammad al-Murtaụā ibn

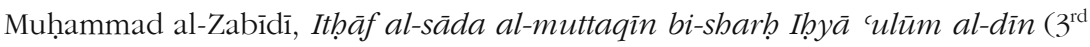
edn., Beirut: Dār al-Kutub al-'Ilmiyya, 2002), II, 8; İsmail Hakkı İzmirli, Yeni Tlm-i Kalām (Istanbul: Awqāf-i Islāmiyya Maṭba'asi, 1339-1341), I, 98.

22 Ṣālih ibn 'Abd al-'Azīz ibn Muhammad ibn Ibrāhīm Āl al-Sheikh, al-La'âlī lbahiyya fì sharh al-'Aqīda al-Wāsițiyya (ed. 'Ādil ibn Muhammad Mursī Rifā'ī; Riyadh: Dār al-'Āṣima, 2010), I, 88-90; Muḥammad Ṣāiḥ al-'Uthaymīn, Sharh al'Aqìda al-Wāsitiyya li-Sheikh al-islām Ibn Taymiyya (ed. Sa'd ibn Fawwāz alȘumayl; $6^{\text {th }}$ edn., Riyadh: Dār Ibn al-Jawzī, 2000), I, 53. Birgiwī, al-Ṭarìqa, 52, 60, 95, 151, 152, 398, 412.

24 Mustafa Çă̆rıc1, "Gazzâlî̀nin İhyâ'sı ile Birgivînnin Tarîkat-1 Muhammadiyye'sinin Mukayesesi," İslâmî Araştırmalar (Gazzâlî Özel Sayısı) 13/3-4 (2000), 473-478.

25 See Mart1, Birgili Mebmed Efendi'nin Hadisçiliği ve et-Tarîkatü'l-Muhammediyye: Tahkik ve Tahlil (PhD dissertation; Konya: Selçuk University, 2005), 290-291.

26 Birgiwì, al-Ṭariqa, 151-153.

27 Birgiwì, al-Ṭariqa, 52, 53, 54, 56, 59, 66, 105, 202, 253, 291, 301, 324, 370, 419-420. 
Some scholars who associate Birgiwī with Ibn Taymiyya have given misleading examples to prove the connection. One of these is the claim that Birgiwi "mentions the name of Ibn Qayyim al-Jawziyya (d. 751/1350)" in al-Tariqa. ${ }^{28}$ The alleged mention of Ibn Qayyim alJawziyya is actually a reference to Abū l-Faraj Ibn al-Jawzī (d. 597/1201), ${ }^{29}$ whose views Birgiwī reports. ${ }^{30}$ Therefore, Abū l-Faraj Ibn al-Jawzī is confused with Ibn Qayyim, the disciple of Ibn Taymiyya. ${ }^{31}$

Another error has been perpetuated by a translation of al-Tariqa by Wadādī called Takmilat al-Tarìqa. ${ }^{32}$ Wadādī's translation does not consist exclusively of text written by Birgiwī. Indeed, Wadādī introduces the work by indicating that "it is called Takmilat al-Tariqa because some passages are derived and added from various books"33 and admits that he has made additions from numerous sources. ${ }^{34}$ Therefore, the references to Ibn Taymiyya in this translation are

28 Lekesiz, XVI. Yüzyıl Osmanl Düzenindeki Değişimin Tasfiyeci (Püritanist) Bir Eleştirisi: Birgivî Mehmed Efendi ve Fikirleri (Phd dissertation; Ankara: Hacettepe University, 1997) 114, and footnotes (hereafter cited as Birgivî Mehmed Efendi ve Fikirleri). Lekesiz refers for the place in which the name Ibn Qayyim is mentioned to the manuscript of al-Tariqa al-Muhammadiyya. The bibliography gives the following citation: MS Ankara: Milli Kütüphane [National Library], Celal Ökten Manuscripts Section, no: 2178, 97b,

(https://www.yazmalar.gov.tr/detay_goster.php?k=66009, 107).

29 Abū l-Faraj 'Abd al-Raḥmān ibn 'Alī Ibn al-Jawzī, Talbīs Iblīs (ed. Sayyid alJumaylī; Beirut: Dār al-Kitāb al-'Arabī, 1994), 224.

30 Birgiwī, al-Ṭarīqa, 196. See also Martı, Birgili Mebmed Efendi'nin Hadisçiliği, 284.

31 Ahmet Kaylı, A Critical Study of Birgiwī Meḅmed Efendīs (d. 981/1573) Works and Their Dissemination in Manuscript Form (MA thesis; Istanbul: Boğaziçi University, 2010), 57 and footnote 137.

32 See Unan, "Dinde Tasfiyecilik," 42 (footnote 55) The author's reference is to this translation, (Birgiwī, Takmila-i tarjama-i Ṭariqat-i Muhammadiyya [translated by Wadādī; Istanbul: Dār al- Salțana, 1256]), 412, 419, 436, 449, 450, 465, 466, 467.

33 Wadādī, Takmila-i tarjama-i Ṭariqat-i Muḥammadiyya (Istanbul: Dār al-Salțana, 1256), 3 .

34 See also İsmail Kara, İlim Bilmez Tarih Hatrlamaz: Şerh ve Haşiye Meselesine Dair Birkaç Not (2 $2^{\text {nd }}$ edn., Istanbul: Dergâh Yayınlar1, 2013), 49; Martı relates that Wadādī later faced criticisms due to his additions to the translation. In her $\mathrm{PhD}$ thesis on al-Tariqa, Mart1 writes, "The name Ibn Taymiyya is not found in any of Birgili [Birgiwī]'s works." Martı, Birgili Mehmed Efendi'nin Hadisçiliği, 126, 331, 332. 
found in the passages added by Wadādī, and do not belong to Birgiwi himself. Most of the views, which are presented in the translation as if they belong to Birgiwi, are indeed nothing but additions by Wadādī. At least some of the comments and criticisms of Birgiwi that are based on this work should be comprehensively reassessed.

Numerous scholars insist on the presence of references to Ibn Taymiyya in Birgiwī's works ${ }^{35}$ referring to a PhD thesis by Yüksel on Birgiwi ${ }^{36}$ In the Turkish translation of his thesis, however, Yüksel indicates that Birgiwi "mentions the name of neither Ibn Taymiyya nor his disciples," noting the discovery that the tract called Ziyārat alqubūr (Visitation of Graves) was not written by Birgiwī. ${ }^{37}$ In a previous study, Yüksel wrote, "we do not find the name of Ibn Taymiyya" ${ }^{38}$ in any work by Birgiwī.

According to scholars who believed in the connection between Birgiwī and Ibn Taymiyya, Ziyārat was considered "the clearest evidence of his awareness of the views of Ibn Taymiyya." ${ }^{39}$ Zivarrat was actually written by Aḥmad ibn Meḥmed al-Rūmī al-Āqhiṣārī alȘarūkhānī (d. 1041/1631); nevertheless, the book was attributed to

35 "An analysis of the books and treatises by Birgiwi clearly reveals the influence of Ibn Taymiyya above all, as well as other subsequent Hanbalī scholars. In his works, Birgiwi often recommends to his readers the books of the persons he mentions and quotes from his references." Ocak, Osmanl Dönemi, 222; id., "İbn Kemâl'in Yaşadığı XV ve XVI. Asırlar Türkiye'sinde İlim ve Fikir Hayat,," in S. Hayri Bolay, Bahaeddin Yediyıldız, and. M. Sait Yazıcıoğlu (eds.), Tokat Valiliğ $i$ Şeyhülislam İbn Kemâl Araştırma Merkezinin Tertip Ettiği Şeybülislâm İbn Kemâl Sempozyumu: Tebliğler ve Tartışmalar ( ${ }^{\text {nd }}$ edn., Ankara: Türkiye Diyanet Vakf1 Yayınları, 1989), 31, 32.

36 Ocak, Osmanl Dönemi, 234, and footnote 17.

37 "Based on the Risālat ziyârat al-qubūr, which is attributed to Birgiwī, I wrote that Birgiwī might have been indirectly influenced by Ibn Taymiyya. ... The paper by Ahmet Turan Arslan (...), however, revealed that the treatise was not written by Birgiwī. Therefore, we have no grounds to claim that Birgiwi, who never mentioned Ibn Taymiyya or his followers in his works, was influenced by Ibn Taymiyya." Emrullah Yüksel, Mehmed Birgivînin Dinî ve Siyasî Görüşleri (Ankara: Türkiye Diyanet Vakfı Yayınları, 2011), 147-148.

38 Yüksel, "Mehmed Birgivî," Atatürk Üniversitesi İslâmı̂ İlimler Fakültesi Dergisi 2 (1977), 184.

39 Lekesiz, Birgivî Mehmed Efendi ve Fikirleri, 114, 115. 
Birgiwī, whereupon it became famous and was printed several times. $^{40}$

Apparently, Shī'a (Rāfiḍa) is the target of the descriptions and related criticisms found in Ziyārat. ${ }^{41}$ Therefore, any relationship between the conclusions derived from any of the information in this tract and members of other groups in the Ottoman era or the assessment of them as Birgiwi's observations of his environment are misleading.

In another work, Majālis al-abrār, al-Āqhiṣārī again addresses issues about graves and refers to Ibn Qayyim and his sheikh (Ibn Taymiyya). ${ }^{42}$ Al-Āqhișārī, as a Ḥanafī scholar under the influence of Ibn Taymiyya, is the subject of various studies. ${ }^{43}$ Importantly, however, al-Āqhișārī is connected to the Māturīè̄ School in his theological discussions. ${ }^{44}$ Al-Āqhiṣārī uses various Kalām and Sufi

40 Ahmet Turan Arslan, "İmam Birgivîye Nisbet Edilen Bazı Eserler," in İbrahim Gümüss (ed.), 1. Ulusal İslam Elyazmaları Sempozyumu (13-14 Nisan 2007) Bildiriler Kitabı (Istanbul: Türkiye Çevre Koruma ve Yeşillendirme Kurumu [TÜRÇEK], 2009), 180-181. See also Yahya Michot, introduction to Against Smoking: An Ottoman Manifesto, by Aḥmad al-Rūmī al-Āqhișārī (ed. and translated by Yahya Michot; Leicestershire: Interface Publications \& Kube Publishing, 2010), 1.

41 The reference to Manāsik al-ḥājj al-mashāhid, which is attributed to al-Sheikh al-Mufīd by Ibn Taymiyya (Ziyārat al-qubūr, in Rasā’il al-Birgiwī [ed. Aḥmad Hādī al-Qașsāar; Beirut: Dār al-Kutub al-'Tlmiyya, 2011], 164) leads us to these opinions. Ibn Taymiyya (d. 728/1328) wrote a refutation called Minhāj al-sunna against Minhāj al-karāma, which was written by contemporaneous Shiite scholar Ibn al-Muțahhar al-Hillī (d.726/1325). In this work, Ibn Taymiyya attributes Manāsik al-ḩājj al-mashāhid to al-Sheikh al-Mufīd, whom he criticizes. See Taqī al-Dīn Ahmad ibn 'Abd al-Halīm Ibn Taymiyya, Minhāj al-sunna al-Nabawiyya (ed. Muḥammad Rashād Sālim; Riyadh: Mu’assasat Qurțuba, 1986), III, 419.

42 Aḥmad al-Rūmī (al-Āqhișārī), Majālis al-abrār, in 'Alī Miṣrī Simjān Fawrā, [Study on] Majālis al-abrār (PhD dissertation; Medina: al-Jāmi`a al-Islāmiyya, 2007), 213, $215,219,654$.

43 For a discussion of Ibn Taymiyya's influence on al-Āqhișārī, see Mustapha Sheikh, "Taymiyyan Influences in an Ottoman-Hanafī Milieu: The Case of Aḥmad al-Rūmī al-Āqhiṣārī," Journal of the Royal Asiatic Society 25/1 (2015), 1-20; Michot, introduction to Against Smoking, 1, 4, 8.

44 'Alī Miṣrī Simjān Fawrā, "Dirāsa" [Study on Majālis al-abrār by Aḥmad al-Rūmī (al-Āqhișāầ)] (PhD dissertation; Medina: al-Jāmica al-Islāmiyya, 2007), 13; Sheikh, 
books as sources and indicates that it is the obligation (wäjib) of every mature believer to derive authentic faith about Ahl al-sunna wa-l-jamāca from the science of Kalām. He asserts that reasoning (nazar) and deduction (istidlāl) are obligatory if one is to know Allah and argues that whoever leaves this path will be a sinner. ${ }^{45}$

\section{Comparison between Birgiwi's and Ibn Taymiyya's Views}

Seeking to establish a connection between Birgiwi and Ibn Taymiyya, researchers have compared the views of the two scholars. These comparisons focus on numerous issues, including the concept of heretical innovation ( $\operatorname{bid}^{c} a$ ). Works by Birgiwi incorporate a variety of significant details on innovation; for example, he uses the concept "al-bid'a al-hasana." ${ }^{46}$ Ibn Taymiyya, however, rejects a division that includes "al-bid'a al-hasana." "'

Another important point to consider regarding the connection between Birgiwi and Ibn Taymiyya is their attitudes towards Sufism. According to Birgiwī, Sufism consists of the purification of the heart from disgrace and its adornment with virtues, and he gives practical advice to its followers (sāliks). ${ }^{48}$ However, Birgiwī criticizes his Sufi contemporaries. ${ }^{49}$ Birgiwi accuses Sufis of claiming to be holders of hidden knowledge, of claiming that they obtain fatwā directly from the Prophet whenever they are in trouble and that otherwise they can access Allah in person and do not need to read scholarly books, etc. For Birgiwī, such Sufi views are false, and whoever hears and believes in them should be considered a heretic (zindīq). Birgiwi criticizes the Sufis of his time as ignorant because they claim that "knowledge is a veil." ${ }^{50}$ In his criticism, Birgiwī respectfully cites alJunayd al-Baghdādī, who says, "our knowledge and madhbab is bound through the Book and Sunna." Moreover, he quotes ${ }^{51}$ the

"Taymiyyan Influences in an Ottoman-Hanafī Milieu," 4.

45 Al-Āqhiṣārī, Majālis al-abrār, 2, 14, 15, 74, 144, 510.

46 For details, see Birgiwī, al-Ṭarīqa, 25-26; Yüksel, Mehmed Birgivî̀nin Dinî ve Siyasî Görüşleri, 67, 68

47 Ibn Taymiyya, Iqtiḍā' al-șirāt al-mustaqīm li-mukhālafat aṣḥāb al-jahìm (ed. Nāșir 'Abd al-Karīm al-'Aql; Riyadh: Maktabat al-Rushd, 1994), II, 585.

48 Birgiwī, al-Ṭariqa, 84, 235, 391-393.

49 Ibid., 28, 47, 67, 362-364.

50 Ibid., 28-29.

51 Ibid., 29-31, 236, 392. 
views of certain great Sufis found in Abū l-Qāsim al-Qushayrī's (d. 465/1072) al-Risāla. ${ }^{52}$ Birgiwī also cites the following phrases from Hanafī scholar Abū 1-Layth al-Samarqandī: "If one learns jurisprudence but does not seek ascetic knowledge and wisdom, his heart hardens. A hardened heart is distant from Allah." ${ }^{53}$

Miḥakk al-șüfiyya, which addresses Sufism and is attributed to Birgiwi ${ }^{54}$ refers to several texts on creeds popular among Ottoman scholars. ${ }^{55}$ The axis proposed by Birgiwi $\overline{1}$ reportedly found many supporters even in Sufi circles. ${ }^{56}$

Birgiwī's criticism of the Sufi practices of raqs and $s a m \bar{a}^{c}$ by music $^{57}$ does not necessarily make him a follower of Ibn Taymiyya. ${ }^{58}$ Indeed, Birgiwī quotes many sources about raqș, including Hanafī fatwā sources. A treatise by 'Umar al-Nasafī, author of one of the most popular creed texts in Hanafī/Māturīì̄ circles and allegedly a member of the $R \bar{a} z \bar{\imath}$ School, ${ }^{59}$ addresses this topic. This treatise by al-

52 Abū 1-Qāsim Zayn al-Islām 'Abd al-Karīm ibn Hawāzin al-Qushayrī, al-Risāla alQushayriyya (eds. 'Abd al-Halīm Maḥmūd and Maḥmūd ibn Sharīf; Cairo: Dār alMacārif, n.d.) 38, 45-46, 48, 57, 58, 61, 79, 87, 98.

53 Birgiwì, al-Ṭariqa, 66-69.

54 Kaylı (A Critical Study of Birgiwī Mehmed Efendi's Works, 138) found copies of this treatise recorded under al-Āqhiṣārī's name; therefore, he claims they might belong to the latter.

55 According to Lekesiz (Birgivî Mehmed Efendi ve Fikirleri, 81), Birgiwī shows Sufis the right path to follow pursuant to the Salafì creed in Miḩakk al-șüfiyya. Nevertheless, the sources of this treatise do not support this finding. In the treatise, Birgiwī refers to the following works on creeds: $a l^{-} A q \bar{a}^{\prime} i d$ by 'Umar alNasafī (p. 11), Iḅyā' by al-Ghazālī (p. 13, 28), al-Mawāqif by al-ījī (p. 14, 17), alFiqh al-akbar by Abū Ḥanīfa (p. 17), and Sharḥ al-'Aqā'id by al-Taftāzānī (p. 19).

56 Terzioğlu, "Bir Tercüme ve Bir İntihal Vakası: Ya da İbn Teymiyye'nin Siyāsetü'şŞer'iyye'sini Osmanlicaya Kim(ler), Nasıl Aktardı?” Journal of Turkish Studies: Türklük Bilgisi Araştırmaları 31/2 (2007), 267.

57 Birgiwī, al-Ṭariqa, 362.

58 Lekesiz, Birgivî Mehmed Efendi ve Fikirleri, 112, 113.

59 This treatise, called Risāla fì bayān madhāhib al-tașawwuf by al-Nasafī, exists in manuscript copies under different names. For information about the publication and translation of the treatise, see Ayşe Hümeyra Arslantürk, "Nesefî, Necmeddin," Türkiye Diyanet Vakfi İslâm Ansiklopedisi (DİA), XXXIII, 572. Al-Hurr al-'Āmilī published this treatise in Risālat al-ithnay 'ashariyya fì l-radd 'alā l-șüfiyya (ed. Muḥammad ibn al-Ḥasan al-Tafrishī al-Darūdī; Qom: al-Maṭba'a al-'Tlmiyya, 1400), 
Nasafî is quoted in Dāmighat al-mubtadi ${ }^{\top} \bar{\imath} n{ }^{60}$ which was attributed to Birgiwī upon publication. ${ }^{61}$ Ottoman scholars prior to Birgiwī have also given fatwā against Sufis who perform raqș and sama $\bar{c}^{62}$

Al-'Urābīi ${ }^{63}$ states that in Dämighat al-mubtadi'inn ${ }^{64}$ there are quotations of critical expressions by Ibn Taymiyya, particularly about

23-25, available at http://www.alhawzaonline.com/almaktaba-almakroaa/ book/238-aqa'ed/0334-al\%20ethna\%203asharia/01.htm (accessed October 3, 2009).

60 In his master's thesis, Dāmighat al-mubtadi'ìn wa-kāshifat buțān al-mulhidìn: al-Imām Muḥammad ibn Pīr 'Alì ibn Iskandar al-Birgiwī-Dirāsa wa-taḥqūqmin awwal al-kitāb ilā qawlib̄i "wa-ammā thawāb al-camal bi-l-sunna" (MA thesis; Mecca: Jāmi'at Umm al-Qurā, n.d.), Sulțān ibn 'Ubayd ibn 'Abd Allāh al'Urābī studies the first chapter of Dāmighat al-mubtadi'ìn. al-'Urābī claims that the published version of Dāmighat al-mubtadi'inn (eds. 'Abd al-Rahīm al-Sāyiḥ and Tawfīq 'Alī Wahba; Cairo: Dār al-Āfāq al-'Arabīyya, 2010) comprises only the chapter studied in his own thesis and that there is no second part. (See https://twitter.com/sultanalorabi/status/462506744607174656, accessed May 3, 2014). Nevertheless, this is misinformation; the end of the text used in al-'Urābī's thesis is on page 150 of the Cairo edition of the book.

61 The expression "ṣāhị al-Bayān" in the text (Birgiwī, Dāmighat al-mubtadicinn, 55) is construed by researcher al- 'Urābī as Abū l-Ma'ālī Muhammad al-Husaynī al'Alawī (d. 485/1092), the author of Bayān al-adyān, though only tentatively (see al-'Urābī, Dāmigha, 216). Nonetheless, an intertextual comparison shows that the quotations are from al-Nasafì. Birgiwī's notes to chapter 23 demonstrate that this information may have been cited from Sirr al-asrār by 'Abd al-Qādir al-Jîlānī. Indeed, chapter 23 of Sirr al-asrār has similar content; see Abū Muhammad 'Abd al-Qādir ibn Abī Ṣālị̣ 'Abd Allāh al-Jīlānī, Sirr al-asrār wa-maẓhar al-anwār fì$m \bar{a}$ yaḥtāju ilaybi l-abrār (eds. Khālid Muḥammad 'Adnān al-Zar'̄̄ and

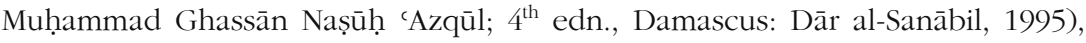
140.

62 Ferhat Koca, "Osmanlı Fakihlerinin Semâ, Raks ve Devrân Hakkındaki Tartışmalar1," Tasavvuf: İlmî ve Akademik Araştırma Dergisi 5/13 (2004), 27, 59. In his study Koca touches upon views of numerous scholars about the issue before and after Birgiwī, including Abū 1-Su'ūd. Also see Reşat Öngören, "Osmanlılar Döneminde Semâ ve Devran Tartısmaları," Tasavvuf: İlmî ve Akademik Araştırma Dergisi 11/25 (2010), 123-132.

63 Al-'Urābī, Dāmigha, 105, 125, 130, 228.

64 Birgiwī, Dāmighat al-mubtadi'īn (eds. 'Abd al-Rahịm al-Sāyiḥ and Tawfīq 'Alī Wahba; Cairo: Dār al-Āfāq al-`Arabiyya, 2010), 60. 
the unity of existence (wahdat al-wujūd) ${ }^{65}$ According to Evstatiev, these findings are based on solid textual analysis and are significant because they enable us to establish a connection between Ibn Taymiyya, Birgiwīe and Qāẹī-zādalis. ${ }^{66}$

The unity of existence (wahbdat al-wujūd) is also criticized by Hanafī scholars such as 'Alā' al-Dīn al-Bukhārī (d.841/1438). ${ }^{67}$ Moreover, 'Alā' al-Dīn al-Bukhārī accuses Ibn Taymiyya of anthropomorphism and claims it would be blasphemy to call him Sheikh al-Islām. ${ }^{68}$ Dāmigha also includes citations from many other scholars. The initial quotations ${ }^{69}$ that appear at the beginning of the book are relevant to this discussion. The first quotation is from alTawdīh, a work on ușül al-fiqh by Șadr al-sharī'a (d. 747/1346). The quotation is about the learning of Kalām, Sufism, and Fiqh together. ${ }^{70}$ The second citation is from Shir'at al-Isläm, the popular work among Ottoman scholars on catechism ( $\left.{ }^{\prime} i l m-i h \hat{a} \bar{l}\right)$ and ethics ( $\left.a k b l \bar{a} q\right)$, by Imām-zāda (d. 573/1177), the Hanafī faqīh. ${ }^{71}$ According to this quotation, whoever demands only Kalām from Allah is a heretic (zindiq), whoever demands only asceticism is an innovator (mubtad ${ }^{\circ}$ ), and whoever demands only jurisprudence is a sinner ( fäsiq). One who displays competence in all attains salvation. ${ }^{72} \mathrm{Al}$ -

65 Ibn Taymiyya, Majmū' fatāwā (ed. 'Abd al-Raḥmān ibn Muḥammad ibn Qāsim; Medina: Mujamma` al-Malik Fahd li-Ṭibā'at al-Muṣhāf al-Sharīf, 2004), II, 122.

66 Simeon Evstatiev, "The Qāḍizādeli Movement and the Revival of takfì in the Ottoman Age," in Camilla Adang, Hassan Ansari, Maribel Fierro, and Sabine Schmidtke (eds.), Accusations of Unbelief in Islam: A Diachronic Perspective on Takfïr (Leiden \& Boston: Brill, 2015), 232.

67 'Alā' al-Dīn al-Bukhārī, Fā diḥat al-mulhidīn, in Muḥammad ibn Ibrāhīm al-'Awḍ̄ī, Fädihat al-mulḅidīn wa-nāṣiḥat al-muwaḅhidīn (MA thesis; Mecca: Jāmicat Umm al-Qurā, 1414).

68 For details, see Khaled el-Rouayheb, Islamic Intellectual History in the Seventeenth Century: Scholarly Currents in the Ottoman Empire and the Maghreb (New York: Cambridge University Press, 2015), 16.

69 Birgiwī, Dāmighat al-mubtadi`īn, 34 .

70 Al-Taftāzānī, Sharḥ al-Talwīḥ 'alā l-Tawdīh li-matn al-Tanqīh fì ușūl al-fiqh (ed. Zakariyyā 'Umayrāt; Beirut: Dār al-Kutub al-'Ilmiyya, 1996), I, 16.

71 Recep Cici, "İmamzâde, Muhammed b. Ebû Bekir," Türkiye Diyanet Vakfı İsâm Ansiklopedisi (DIA), XXII, 210-211.

72 Sayyid 'Alī-zāda, Mafātīḥ al-jinān: Sharh Shir'at al-Islām (Istanbul: al-Maṭba'a al'Uthmāniyya, 1317), 41. 
'Urābī indicates that he could not obtain any information about Shir at al-Isläm. ${ }^{73}$ However, he notes some details about the joint publication of some of Birgiwi's works with commentaries on Shir'at al-Islām. ${ }^{74}$ Al-'Urābī draws other erroneous conclusions about Hanafī authors referenced in the Dämigha who wrote particularly about issues related with Sufism. Also, it could be noted that there is a fatwā that Shir'at al-Isläm should not be allowed to be read, because it includes nonsense stuff such as those in Ibyya by al-Ghazāli. The fatwā allows only those who know the Sufi creed and have specialized knowledge of the Salafĩ creed to read Shir'at al-Islām. ${ }^{75}$

Dāmigha includes long citations from al-Ghazālī. For example, one citation from al-Ghazālī's Minhāj al-'ābidīn ${ }^{76}$ covers many pages ${ }^{77}$ Nevertheless, sources that are more or less contemporaneous with Birgiwī do not attribute the Dämigha to him. Hadiyyat al-'ärifin by 'Ismā̄īl Pāshā al-Baghdādī (d. 1920) and subsequent authors of bibliographical works mention Dāmigha to have been authored by Birgiwī. The assertion that the lack of association between Birgiwi and this work during his lifetime was due to his fear of Sufi molestation is groundless. ${ }^{78}$ Indeed, he fearlessly addresses and criticizes many other controversial aspects of Sufism in al-Tariqa and other works. Janābī Mușțafā Efendī (d. 999/1590) asserted that Birgiwì never refrained from telling the truth for Allah's sake, even when he addressed the Sultan. ${ }^{79}$

An analysis of the creed issues shows that Dämigha was written by a Māturīin scholar. According to the author, men are equal in faith and differ in their deeds, but deeds are not a part of faith. It is necessary (wäjib) to know Allah (Șänic) through reason; moreover, the good or evil nature of things can be known through reason. For

73 Al-'Urābī, Dāmigha, 161.

74 Ibid., 82, 83, 84.

75 http://fatwā.islamweb.net/fatwā/index.php?page=showfatwā\&Option= FatwāId\& Id=118878 (accessed February 5, 2016).

76 Abū Hāmid Muḥammad ibn Muḥammad ibn Muḥammad al-Ghazālī, Minhāj al'ābidinn ilā jannat Rabb al-'ālamīn (ed. Maḥmūd Muștafā Halāwī; Beirut: Mu'assasat al-Risāla, 1989), 112, 114, 117.

77 Birgiwī, Dāmighat al-mubtadi'ìn, 203, 207, 230.

78 For details, see al-'Urābī, Dāmigha, 101-103.

79 Al-Janābī, 'Aylam al-zākhir, 427a. 
the author, man would be responsible to believe in Allah even if no prophet were sent because reasoning and deduction are man's primary obligations. He interprets attributes of Allah such as his hand, face, descent etc. by associating them with meanings such as His power or His favour. ${ }^{80} \mathrm{~A}$ scholar with such views would be considered a Māturīīi.

\section{Relationship between Ibn Taymiyya, Birgiwī, Qāọīzādalīs and Wahhābism}

The Qāḍizādalīs' and Wahhābīs' interventionist attitudes toward society's religious life result in a tendency to establish a connection between these two groups. Therefore, the views of Birgiwi and Ibn Taymiyya, two reputable references of these sects, are often compared, especially on the base of their views that constitute the foundation of an interventionist approach. Indeed, it could be asserted that there are contradictions between the writings of Birgiwi and the practices of his followers. Sources reveal that Birgiwī was typically direct and blunt. According to Janābī Muștafā Efendī, Birgiwī was a strictly religious person (mutasharric) who feared molestation from nobody when he told the truth for Allah's sake. He was determined about commanding good and forbidding wrong (al-amr bi-l-ma'rüf wa-l-naby 'an al-munkar), even if he addressed the Sultan. He was a custodian of the Qur'ān and a patron of knowledge and had an abstemious personality with regard to eating and clothing. ${ }^{81}$ Cook emphasizes Birgiwi and his followers' views about the prevention of evil. ${ }^{82}$

For Birgiwī, commanding good and forbidding wrong is a communal obligation (fard al-kifāya) that must be sufficiently discharged, if can afford, on condition that not to harm people. The expressions found in verses $(\bar{a} y a)$ and hadiths indicate that this is an obligation for every person. In contrast, commanding wrong and forbidding good is the attribute of hypocrites, ${ }^{83}$ as indicated in the

\footnotetext{
80 Birgiwī, Dāmighat al-mubtadi'ìn, 220.

81 Al-Janābī, 'Aylam al-zākhir, 427a.

82 Michael Cook, Commanding Right and Forbidding Wrong in Islamic Thought (Cambridge: Cambridge University Press, 2004), 323.

83 Birgiwī, al-Ṭariqa, 281.
} 


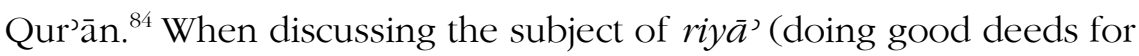
show), Birgiwi gives following examples: to manifest knowledge during sermons and discourses, to show care for the attitudes of Salaf, to command good before the public, to show anger against evil and to seem worried about $\sin ^{85}$ When addressing sedition (fitna), Birgiwī speaks to preachers and muftīs about how to prevent sedition among the people. Birgiwi recommends that they remain aware of the customs of the public, of what people may accept or reject, of what they strive to fulfill or seek to avoid. He also advises that the public be addressed in the most appropriate manner possible. Any deed intended to command good and forbid wrong could become a sin if it leads to the promotion of evil or pushes someone into an undesired position. About the hazard of sedition, the verse "fitna is worse than killing" ${ }^{\prime 86}$ is more than enough. ${ }^{87}$ The records of conflicts among Birgiwì's followers are proof that his warnings were overlooked. Moreover, there appear to have been different mentalities among those who read his works.

Several studies about the Qādīizādalīs indicate their relationship with Birgiwīi ${ }^{88}$ Both Birgiwī and the Qādìzādalīs are mentioned in connection with Ibn Taymiyya and the Wahhābis.

The Salafì movement, started by Ibn Taymiyya, gave birth to the Birgiwi

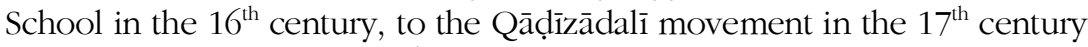
and to Wahhābism in the $18^{\text {th }}$ century within the Ottoman Empire. ${ }^{89}$

Michot dubs Birgiwī the "spiritual father of Ottoman Puritanism" and argues that the Qāḍizāàdali movement, which emerged under the influence of Ibn Taymiyya and Ibn Qayyim, was the precursor of Wahhābism. ${ }^{90}$ For Currie, there is a striking similarity between the

\section{Q 9:67.}

85 Birgiwī, al-Ṭarīqa, 90.

86 Q 2:191.

87 Birgiwī, al-Ṭarīqa, 224.

88 Madeline C. Zilfi, The Politics of Piety: The Ottoman Ulema in the Postclassical Age: 1600-1800 (Minneapolis: Bibliotheca Islamica, 1988), 143.

89 Ocak, Osmanl Dönemi, 218-219. For comparison, see id., "İbn Kemâl'in Yaşadığ XV ve XVI. Asırlar Türkiye'sinde İlim ve Fikir Hayat1," 31, 32; id., "Religious Sciences and the Ulema," 263; Lekesiz, Birgivî Mehmed Efendi ve Fikirleri, 106. 
Qādịizādalīs and the Wahhābīs, and he cites several scholars to establish a connection between the two groups. ${ }^{91}$

An important source of evidence for the connection between Ibn Taymiyya and the Qādīzādalīs is the Turkish translation of Ibn Taymiyya's al-Siyāsa al-shariyya. This translation is attributed to Qāụī-zāda Meḥmed Efendī (d. 1045/1635). ${ }^{92}$

'Āshiq Chalabì (d. 979/1572) made an expanded translation of this work by Ibn Taymiyya into Ottoman Turkish under the title Micrāj al'iyāla wa-minhāj al-'adāla and presented to Selīm II, the Sultan of the Ottoman State. Tāj al-rasā'il wa-minhāj al-wasā'il (or Nuṣh albukkām sabab al-nizām), reportedly translated by Qāọī-zāda, makes certain additions to the translation by 'Āshiq Chalabī. Qādīizāda Mehmed presented his translation to Murād IV (r. 1623-40), the Ottoman Sultan. ${ }^{93}$

One who accepts certain statements in the text by Qāḍi-zāda can by no means be a follower of the Ibn Taymiyya School. One example will be sufficient. According to the text, there are four letters in the name of Sultan 'Murād,' and this is equal to the number of letters in the word 'Allah,' this coincidence comprises countless mysteries. ${ }^{94}$

In her study of this translation, Terzioğlu declares that Qāḍi-zāda's translation was plagiarized from 'Âshiq Chalabī and notes the following:

Recently, many modern historians interested in this movement (Qāḍizādalis) bear in the back of their minds the parallelism between this

91 James Muḥammad Dawud Currie, "Kadizadeli Ottoman Scholarship, Muhammad ibn 'Abd al-Wahhāb, and the Rise of the Saudi State," Journal of Islamic Studies 26/3 (2015), 265-288.

92 Ocak, Osmanl Dönemi, 224.

93 Vecdi Akyüz, "Preface," in Ibn Taymiyya, Siyâset: es-Siyâsetü'ş-şer'iyye (translated into Turkish by Vecdi Akyüz; $2^{\text {nd }}$ edn., Istanbul: Dergâh Yayınlar1, 1999), 6-7.

94 Qāḍī-zāda Meḥmed [Muḥammad ibn Muștafā ibn Muḥammad], Tāj al-rasā’il waminhāj al-wasā’’il (MS Istanbul: Süleymaniye Library, Hacı Mahmut Efendi, 1926), 11a-b. A similar assessment is made by 'Āshiq Pāshā, who made an earlier translation of the same book, about the fact that the name of Selim II, the Sultan of the Ottoman State, consists of four letters. See Pīr Muhammad ibn 'Alī ibn Muhammad 'Āshiq Chalabī, Mi rrāj al-'iyāla wa-minhāj al-'adāla (MS Istanbul: Süleymaniye Library, Şehid Ali Paşa, 1556), 14. 
movement and various 'radical,' 'fundamentalist,' or - as a less political and more academic expression - 'salafî' Islamic movements. Furthermore, several historians consider Ibn Taymiyya as an important junction within the intellectual genealogy of such Islamic movements and accordingly want to establish a connection between the Qāḍizādalīs and the Ibn Taymiyya School. Nevertheless, neither Ibn Taymiyya nor his al-Siyāsa al-shar'iyya seems to have been a particular inspiration for the Qāḍīzādalī - sharī́a emphasized movement that appeared in the $17^{\text {th }}$ century. ${ }^{95}$

As is seen in the example of 'Āshiq Chalabī, you do not have to be on the 'Salafī,' as described today, axis to translate a text by Ibn Taymiyya. Indeed, neither Qāḍī-zāda Meḥmed of Balıkesir nor Mehmed Effendi of Birgi, the main inspiration of the movement named after him in the $16^{\text {th }}$ century, grant a special place to Ibn Taymiyya in their respective works. ${ }^{96}$

\section{Remarks on Birgiwī's Views on Kalām}

For Birgiwī, 'ilm al-kalām is a communal obligation (fard alkifäya). ${ }^{97}$ Nevertheless, it should be learned and taught by those who are faithful and clever and have no sympathies with deviant sects. ${ }^{98}$ Kalām includes logic. ${ }^{99}$ Birgiwī's attitude toward Kalām and logic is

95 Terzioğlu, "Bir Tercüme ve Bir İntihal Vakası," 270.

96 Ibid., 266. Referring to a PhD thesis by Hüseyin Y1lmaz, Terzioğlu argues that Birgiwī's works include references to Ibn Qayyim al-Jawziyya but not to Ibn Taymiyya. Y1lmaz makes a similar claim, referring to a paper titled "Mehmed Birgiwî" by Emrullah Yüksel. See Hüseyin Y1lmaz, The Sultan and the Sultanate: Envisioning Rulership in the Age of Süleymān the Lawgiver (1520-1566) (PhD dissertation; Ann Arbor: Harvard University, 2005), 78. As mentioned above, Yüksel, in his subsequent writings, indicates that "Birgiwī never mentioned the name of Ibn Taymiyya or his disciples in his works;" these findings should be reassessed.

97 A master's thesis has been written about Birgiwī's views on Kalām. Nevertheless, we could not obtain this thesis. 'Āṭif Ibrāhīm Aḥmad, al-Birgiwī wa-ārā'ub ${ }^{\bar{u}} l$ kalāmiyya (MA thesis; Cairo: Jāmicat al-Qāhira, 2013), available at http://cu.edu.eg/ar/Cairo-University-Faculty-News-2489.html (accessed April 18, 2013).

98 Birgiwī, al-Ṭariqa, 53.

99 Ibid., 55. See also Khaled El-Rouayheb, "The Myth of 'The Triumph of Fanaticism' in the Seventeenth-Century Ottoman Empire," Die Welt des Islams 48/2 (2008), 200 . 
considered explicit evidence that he was not influenced by Ibn Taymiyya. ${ }^{100}$

The theological opinions of Birgiwī can be found in his Wașiyyatnama, several tracts and a chapter dedicated to the subject in alTarīqa. ${ }^{101}$ Al-Risālat al-i'tiqāadiyya, ${ }^{102}$ a work containing detailed and systematic information on theological issues and considered the Arabic version of Wașiyyat-näma, was published under the name of Yahyā ibn Abī Bakr (d. 893/1488). ${ }^{103}$

It has been found that Birgiwī based his writings about kalām in

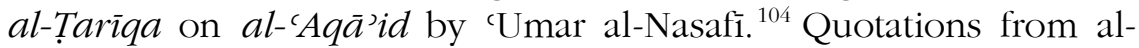
Nasafi's text are frequent, as are certain extracts, changes in order, varying expressions, and additions. Birgiwī presents a 'Māturīì̄ creed' in short. ${ }^{105}$

Birgiwī accuses certain Sufis of valuing awliy $\bar{a}^{\prime}$ above the Prophet, referring to al-Jurjānī's Sharḅ al-Mawāqif and to Sharḅ al-Maqāṣid

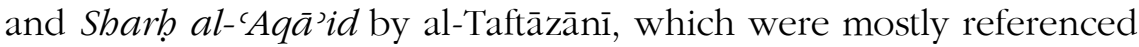
works by Ottoman scholars. ${ }^{106}$

Dämighat al-mubtadi ìn, which is attributed to Birgiwī, also deals with theological issues in some parts, assesses the views of other

100 El-Rouayheb, "From Ibn Hajar al-Haytamī (d. 1566) to Khayr al-Dīn al-Ālūsī (d. 1899): Changing Views of Ibn Taymiyya among non-Hanbalī Sunnī Scholars," in Yossef Rapoport and Shahab Ahmed (eds.), Ibn Taymiyya and His Times (Karachi: Oxford University Press, 2010), 103.

101 Birgiwī, al-Ṭariqa, 44.

102 For an introduction to the contents of these works, see Mart1, Birgivî Mehmed Efendi: Hayatı, Eserleri ve Fikir Dünyası, 74.

103 Marie Bernand, "Le muḩtașar fī bayān al-i'tiqād," Annales Islamologiques 18 (1982), 1-33.

104 Yüksel, Mehmed Birgivî'nin Dinî ve Siyasî Görüşleri, 57, 71, 72.

105 Mart1, "Tarîkat-1 Muhammediyye," Türkiye Diyanet Vakfi İslâm Ansiklopedisi (DíA), XL, 107. Amīr Mușțafā (d. 1143/1731), who translated al-Ṭariqa and is known as a "țariqa man/țariqatchī" due to his lectures on al-Ṭariqa (see Mart1, Birgili Mehmed Efendinin Hadisçiliği, 199, 336), also translated the chapter about creed in al-Tariqqa into Turkish under the title Farā'id al-'aqa'id albahiyya and comprehensively commented on them (see Țarīqatchī Amīr Mușțafā, Farā'id al-'aqā'id al-bahiyya fì hall mushkilāt al-Ṭariqa al-Muḥammadiyya (MS Istanbul: Nuruosmaniye Library, no: 2318).

106 Birgiwī, al-Ṭarīqa, 43, 47. 
madhhabs and passes judgments on them. For al-'Urābī, the similarity of chapters including judgments on madhbabs in Dämigha $a^{107}$ and al-Tariqqa ${ }^{108}$ is proof that Birgiwi is the author of Damigha ${ }^{109}$ Nevertheless, these similarities do not necessarily mean that both were written by the same author. Indeed, the texts resemble one another because they are based on the same sources. More precisely, both works refer to the Hanafī fatwā books, al-Bazzāziyya and al-Tātārkhāniyya ${ }^{110}$ and mention these by name. In fact, Dāmigha quotes from al-Bazzāziyya and gives its author as al-Zāhid who is also explicitly mentioned as al-Zāhid al-Ṣaffār in alBazzāziyya; ${ }^{111}$ however, perhaps because he did not read alBazzāziyya, al-'Urābī erroneously identifies al-Zāhid as the Mu'tazilīHanafī scholar Abū 1-Rajā̄ Najm al-Dīn Mukhtār al-Zāhidī (d. 658/1260). ${ }^{112}$ A comparison clearly shows, however, that the judgments about madhhabs were quoted from Māturīdī scholar alZāhid al-Ṣaffār al-Bukhārîi ${ }^{113}$ (d. 534/1139).

We will not discuss all of Birgiwī's views on Kalām; instead, we will limit the discussion to several controversial points attributed to him. Several researchers have drawn different conclusions about which madhhab Birgiwī belongs to.

Al-'Urābī claims that Birgiwī belongs to the Ibn Taymiyya School. ${ }^{114}$ For al-'Urābī, Birgiwī "has a tendency to express Māturīdī/Hanafī views on some theological issues." 115 Nonetheless,

\footnotetext{
107 Birgiwī, Dāmighat al-mubtadicìn, 51.

108 Birgiwī, al-Tarīqa, 44.

109 Al-'Urābì, Dāmigha, 102-103.

110 Farīd al-Dīn 'Ālim ibn al-'Alā' al-Indarapatī al-Dihlawī, al-Fatāwā lTātārkhāniyya (ed. Shabbīr Aḥmad al-Qāsimī; Deoband: Maktabat Zakariyyā', 2010), VII, 286, 363.

111 Hāẩ al-Dīn Muḥammad ibn Muḥammad ibn Shihāb al-Kardarī al-Bazzāzī (Ibn alBazzāzì), al-Fatāwā l-Bazzāziyya [in the marginal note of al-Fatāwā l-Hindiyya fì madhhab al-Imām al-A`zam Abì Hanīfa al-Nu'mān] (Būlāq: al-Mațba'a alKubrā al-Amīriyya, 1310), VI, 318.

112 Al-'Urābī, Dāmigha, 197.

${ }^{113}$ Abū Isḥāq Ibrāhīm al-Ṣaffār al-Bukhārī, Talkhīs al-adilla li-qawā id al-tawḥ̄d (ed. Angelika Brodersen; Beirut: Orient Institut, 2011), 727.

114 Al-'Urābī, Dāmigha, 52, 105, 125, 130.

115 Ibid., 54.
} 
the issues indicated by al-'Urābī as 'some' are crucial for determining Birgiwī's madhhab; indeed, whenever a difference emerges, Birgiwi adopts the Māturīdī approach. Therefore, it is inaccurate to associate him with the Ibn Taymiyya School. Researchers with Salafī/Wahhābi views who studied Birgiwi often rejected theological views of Birgiwi in the introduction (dirāsa) of their works referring Ibn Taymiyya. ${ }^{116}$

\section{Tawhịid}

Birgiwi begins his remarks about faith in al-Ṭariqa by stating, "Allah is only one." ${ }^{117}$ After stating that Birgiwī classifies divine unity (tawhị $\bar{d}$ ) pursuant to the Māturīdī approach, al-'Urābì claims that no salvation is possible without incorporating unity of worship (tawhīd $a l-{ }^{-} i b \bar{a} d a$ ) into the concept of unity. Ibn Taymiyya divides unity in types and claims that one cannot become monotheist and a believer without accepting unity of worship. Noting that polytheists of Mecca accepted the unity of God without unity of worship, ${ }^{118}$ Ibn Taymiyya says that "they were, however, polytheists; their belief in unity did not help them." ${ }^{119}$ This shows the approach of al-'Urābī, who quotes these phrases by Ibn Taymiyya ${ }^{120}$ and considers salvation impossible without unity of worship, towards Birgiwī and the Māturīiñ views.

According to Birgiwī, the faith of an imitator (muqallid) is valid; nevertheless, an imitator is a sinner because his beliefs are not based on evidence. Imitation is one of the troubles of the heart and is not permissible in creeds. Reasoning and evidence are needed, even if they are not in-detail (wa-law 'ala tarìq al-ijmāl). Indeed, there are several Qur’ān verses that encourage reasoning and denigrate

\footnotetext{
116 The following master's thesis is among the relevant studies: Fuhayd ibn Manșū ibn Zāmil ibn Lu’ayy al-Sharif, introduction to Aḅwāl atfāl al-muslimìn, by Birgiwī (MA thesis; Mecca: Jāmi`at Umm al-Qurā, 1434).

117 Birgiwī, al-Ṭarīqa, 39. Also see id., Vasiyyet-nâme, 95; Țarīqatchī, Farā'id, 2b; Qāụī-zāda Aḥmad [as Kadıâde Ahmed], Birgivî Vasiyetnâmesi: Kadizâde Şerhi (simplified by A. Faruk Meyan; Istanbul: Bedir Yayınları, 2009), 22.

118 Ibn Taymiyya, Dar’ ta'āruḍ al-‘aql wa-l-naql (ed. Muhammad Rashād Sālim; $2^{\text {nd }}$ edn., Medina: Jāmi`at al-Imām Muḥammad ibn Su'ūd al-Islāmiyya, 1991), I, 225.

119 Ibn Taymiyya, al-Tadmuriyya: Taḥqīq al-ithbāt li-l-asmā' wa-l-ṣifāt wa-ḥaqūqat al-jam' bayna l-qadar wa-l-shar' (ed. Muhammad ibn 'Awda al-Sa'wī; Riyadh: Maktabat al-'Ubaykān, 2000), 179.

120 Al-'Urābī, Dāmigha, 55.
} 
imitation in faith. ${ }^{121}$ A passage in Dāmigha reads, "The first obligation of a mature responsible believer is reasoning." ${ }^{122}$ Ibn Taymiyya, however, criticizes the Kalām scholars who assert that reasoning is the primary obligation of the responsible person. ${ }^{123}$

\section{Divine Attributes}

In al-Tarīqa, Birgiwī lists eight affirmative attributes of God (alsifät al-thubütiyya): life (bayāt), knowledge ('ilm), power (qudra), hearing (sam), seeing (bașar), will (irāda), speech (kalām) and bringing into being (takwin). ${ }^{124}$ Bringing into being is a muchdisputed issue between the Ash'arī and Māturīdī scholars. ${ }^{125}$ Birgiwì's inclusion of takwin among the eternal attributes of Allah shows his adherence to the Māturīìi School. ${ }^{126}$

When discussing these attributes, Birgiwī indicates that Allah is not a matter (jism), substance (jawhar), or accident ('arad) (et cetera). ${ }^{127}$ According to Ibn Taymiyya, the expression of the existence or nonexistence of matter, substance, and accident etc. for Allah ( $\bar{l} \bar{a}$ nafy $w a-l \bar{a} i t h b \bar{a} t)$ is among the heretical innovations censured by Salaf ( min kalām al-mubtadic). ${ }^{128}$

For Birgiwī, the vision of God is possible $\left(j \bar{a}^{\prime} i z\right)$ in terms of reason, and obligatory $(w \bar{a} j i b)$ in terms of revelation. However, there is no space, direction or distance for that vision. ${ }^{129}$ Al- 'Urābī assesses this view from a Salafī perspective, saying, "People will laugh off one who says Allah will be seen albeit there is no direction." ${ }^{130}$ Birgiwi refers to fatwā books to make the claim that any word that attributes

\footnotetext{
121 Birgiwī, al-Tarīqa, 41, 95.

122 Birgiwī, Dāmighat al-mubtadi'ìn, 223; al-'Urābī, Dāmigha, 57.

123 Ibn Taymiyya, Majmū' fatāwā, XVI, 328.

124 Birgiwī, al-Ṭariqa, 39.

125 Al-Khādimī, al-Barīqa, I, 211, 315; Ṭarīqatchī, Farā’id, 29a; al-Taftāzānī, Sharḅ al-Maqāṣid, V, 232; al-Zabīdī, Itḥāf al-sāda, II, 8, 250; Kalayc1, Taribsel Süreçte Eşarilik-Maturidilik İlişkisi, 288.

126 Yüksel, Mehmed Birgivî’nin Dinî ve Siyasî Görüşleri, 72.

127 Birgiwī, al-Ṭariqa, 39.

128 Ibn Taymiyya, Majmū' fatāwā, III, 81.

129 Birgiwī, al-Ṭariqa, 39-40.

130 Al-'Urābī, Dāmigha, 68.
} 
space to Allah will become unbelief. ${ }^{131}$ This view of Birgiwi is evidence of his differentiation from Ibn Taymiyya. ${ }^{132}$

According to Birgiwi, Allah is the creator of good and evil, including the deeds of his objects (' $a b d s$ ). In turn, the object has free will to choose his actions that is subject to reward or punishment. ${ }^{133}$ Similar opinions are expressed in Dämigha ${ }^{134}$ Birgiwì's thoughts on human deeds and free will are entirely compliant with the HanafiMāturīdī approach. ${ }^{135}$ Birgiwi criticizes the Ash'arī conception of predestination. Mentioning the name of al-Ash'arī, Birgiwī claims that his view called al-jabr al-mutawassit is actually no different than aljabr al-maḥd. Although he does not mention Māturīdī, his explanations fit the Māturīdī perspective. ${ }^{136}$ Moreover, Birgiwī and his al-Tariqa are believed to have a special role in the spread of the concept of the particular will (al-irāda al-juz'iyya), which is highly relevant to this topic. ${ }^{137}$ For Birgiwi, the object cannot be held responsible for something that exceeds its power; ${ }^{138}$ therefore, he must be affiliated with the Māturīdī approach because he differs from the Ash'arī approach. ${ }^{139}$

\section{Faith (Īmān)}

According to Birgiwī, faith is to approve (tașdīq) and acknowledge (iqrār) those things clearly brought by the Prophet. ${ }^{140}$ Deeds are not included in the truth of faith. Faith is synonymous with Islām. Faith neither increases nor lessens. It is not permissible to say, "I am a believer, inshā’ Allāh" (exception in faith). ${ }^{141}$ Birgiwī's views accord

\footnotetext{
131 Birgiwī, al-Ṭariqa, 43.

132 El-Rouayheb, Islamic Intellectual History, 15.

133 Birgiwī, al-Ṭariqa, 40; Țarīqatchī, Farā'id, 54b.

134 Birgiwī, Dāmighat al-mubtadi ‘̀̃n, 225, 226.

135 Yüksel, Mehmed Birgivî̀nin Dinî ve Siyasî Görüşleri, 93.

136 Birgiwī, al-Ṭariqa, 118. For details, see Çağrıcı, "Gazzâlî’nin İhyâ'sı ile Birgivî̀nin Tarîkat-1 Muhammediyye'sinin Mukayesesi," 477.

137 Philipp Bruckmayr, "The Particular Will (al-irādat al-juz'iyya): Excavations Regarding a Latecomer in Kalām Terminology on Human Agency and Its Position in Naqshbandi Discourse," European Journal of Turkish Studies 13 (2011), 4.

138 Birgiwī, al-Ṭariqa, 40.

139 Țarīqatchī, Farā'id, 61b.

140 Birgiwī, al-Tarīqa, 41, 84.

141 Birgiwī, al-Ṭarīqa, 41; cf. Birgiwī, Vasiyyet-nâme, 104; Ṭarīqatchī, Farā’id, 120a.
} 
with those of al-Imām al-Māturīīi on īmān and Islām. ${ }^{142}$ Ibn Taymiyya mentions al-Māturīdī and his belief that "all human are equal in terms of faith; faith either is or is not, it is indivisible," a view that differs from his own. ${ }^{143}$

For Ibn Taymiyya, the definition of faith as "approval of heart, acknowledgement of tongue" is actually associated with Murji'a. ${ }^{144}$ It is permissible to say, "I am a believer, inshā' Allāh" (exception in faith). ${ }^{145}$ İmān and Islām are different. ${ }^{146}$ Deeds are part of faith. ${ }^{147}$ Faith increases and lessens; ${ }^{148}$ it changes and becomes fragmentary in terms of virtue. ${ }^{149}$ The divisions that constitute faith, may partially fade away or survive. ${ }^{150}$

Once deeds are included within the description of faith, some interesting interpretations inevitably follow. According to Ibn Qayyim, a disciple of Ibn Taymiyya, unbelief and belief, polytheism and unity, piety and wrong, hypocrisy and faith may be simultaneously present in a person. This is one of the most fundamental principles. Ahl al-bid'a, however, opposes this argument. ${ }^{151}$ Though he expresses himself differently, Ibn Taymiyya seems to have adopted the same approach. ${ }^{152}$ Nevertheless, we should also note his acceptance of "unbelief that does not dismiss one from religion" (kufr lā yanqul 'an al-milla, kufr dūn kufr). ${ }^{153} \mathrm{~A}$

\footnotetext{
142 Yüksel, Mehmed Birgivî̀nin Dinî ve Siyasî Görüşleri, 94, 95.

143 Ibn Taymiyya, Majmū' fatāwā, VII, 582.

144 Id., al-İmān (ed. Muhạmmad al-Zubaydī; Beirut: Dār al-Kitāb al-'Arabī, 1993), 172; id., Majmū' fatāwā, XIII, 50.

145 Id., al-İmān, 384-388; id., Majmū' fatāwā, VII, 439, 509.

146 Ibn Taymiyya, Majmū' fatāwā, VII, 6.

147 Ibid., III, 151, 177; VII, 308, 330, 642.

148 Ibn Taymiyya, al-İmān, 28, 32, 204, 211, 216, 279, 308, 330; id., Majmū' fatāwā, III, 151; VI, 479; VII, 223, 505; XIII, 51; XIX, 188.

149 Ibn Taymiyya, Majmū' fatāwā, III, 355; VII, 517, 647; XI, 654; XVIII, 270.

150 Ibid., VII, 517.

151 Abū 'Abd Allāh Shams al-Dīn Muḥammad Ibn Qayyim al-Jawziyya, Kitāb al-ṣalāt (ed. 'Adnān ibn Șāfākhān al-Bukhārī; Mecca: Dār al-'Ālam al-Fawā'id, 1431), 60.

152 Ibn Taymiyya, Majmū' fatāwā, VII, 353, 404, 520.

153 Ibid., VII, 350, 312, 325.
} 
person who commits a major sin (murtakib al-kabira) is a believer with incomplete faith (nāqis al-īmān). ${ }^{154}$

According to Wahhābī commentators of Ibn Taymiyya, Māturīdiyya is out of Ahl al-sunna; it is a deviant (dälla) sect. ${ }^{155}$ Birgiwī adopts the same views as the Māturīdī scholars about faith and almost all theological issues discussed among other Sunnī madhbabs. Therefore, it is impossible to claim that Birgiwi is affiliated with the Ibn Taymiyya School or Wahhābism.

\section{Conclusion}

Birgiwī has been described as a 'Salafî' and a representative of the Ibn Taymiyya School of the Ottoman Empire. Nevertheless, when we elaborate various studies, we can see that the concepts developed on Ibn Taymiyya School and its alleged represantative Birgiwi are complicated. Birgiwì's dissenting character in several controversial issues during his lifetime has been highlighted. The sensitiveness in some issues such as criticisms against those who are considered heretics and Sufi circles has been widely seen as if they are specific to only Ibn Taymiyya and mentioned only in Ibn Taymiyya's work. As Birgiwī hints in his notes, the Hanafī circle and tradition had already dealt with these issues and dissenting opinions; thus, it is a deficiency to overlook and ignore this fact.

Assumptions have been made about the relationship between Ibn Taymiyya and Birgiwī. Because of the discovery that Ziyārat alqubūr was not written by Birgiwī, it is necessary to review the arguments asserting this connection that have been based on this treatise. The references to translations of Birgiwì's al-Tariqa also require revision because they are occasionally based on additions by the translator and not on Birgiwì's original writings. Moreover, the findings based on erroneous information, such as the confusion of Ibn Qayyim, a disciple of Ibn Taymiyya, with Abū l-Faraj Ibn al-Jawzī, who lived and died in an earlier period, should be corrected. There are some quotations in Dämighat al-mubtadi'in that have been attributed to Birgiwī. Nevertheless, there are doubts about whether

\footnotetext{
154 Ibid., VII, 354.

155 Āl al-Sheikh, al-La'ālì l-bahiyya, 88-90; al-'Uthaymīn, Sharḅ al-'Aqìda alWāsitiyya, I, 53.
} 
the book was really written by Birgiwī. Moreover, its contents reveal a completely Māturīdī text.

Birgiwī's views are consistent with the Māturīdiyya from the conventional classification of three sub-categories of Sunni Islam: Salafiyya, Māturīdiyya and Ash`ariyya. It is noteworthy that who assessed Birgiwī's thoughts with a Salafī approach found them ridiculous or associate with the ideas of polytheists. On the other, the traditional categorization of Ottoman religious thought as the Rāzi (Māturīdī) School and Ibn Taymiyya School is also open to criticism in terms of madhhabi identities. Recognizing this, this study aimed to reveal the issues of Birgiwì's madhbabi association. Considering Birgiwi's views on creeds, it seems impossible to dissociate him from the Māturīīis and to categorize him as a member of the Ibn Taymiyya School. Birgiwī is a Hanafī scholar, sensitive to religious deviations in society, and affiliated with Māturīdī approaches to theological problems. Various sub-classifications may be established within Māturīdism. Indeed, Māturīdism is represented in different ways in different regions. However, it seems impossible to trace the Ibn Taymiyya School of the Ottoman Empire through Birgiwī. The developments that occurred after Birgiwi's death also require further study.

\section{ACKNOWLEDGMENTS}

I would like to express my gratitude to Kadir Gömbeyaz for proofreading and commenting on this study.

\section{REFERENCES}

Aḥmad, 'Āṭif Ibrāhīm, al-Birgiwì wa-ārā'u $b^{u}$ l-kalāmiyya (MA thesis; Cairo: Jāmi'at al-Qāhira, 2013), available at http://cu.edu.eg/ar/CairoUniversity-Faculty-News-2489.html (accessed April 18, 2013).

Akyüz, Vecdi, "Preface", in Taqī al-Dīn Ahmad ibn 'Abd al-Halīm Ibn Taymiyya, Siyâset: es-Siyâsetü'ş-Şer'iyye (translated into Turkish by Vecdi Akyüz; $2^{\text {nd }}$ edn., Istanbul: Dergâh Yayınları, 1999).

al-Āqhịịārī, Aḥmad al-Rūmī, Majālis al-abrār (the first fifty session), in 'Alī Miṣrī Simjān Fawrā, [Study on] Majālis al-abrār (PhD dissertation; Medina: al-Jāmi`a al-Islāmiyya, 2007).

al-Āqhișārī, Aḥmad al-Rūmī [as el-Akhisârî, Ahmed er-Rûmî], Tütün İçmek Haram midır? Bir Osmanlı Risalesi [=Against Smoking: An Ottoman 
Manifesto] (translated by Mehmet Yavuz; İstanbul: Kitap Yayınevi, 2015).

'Alī ibn Bālī, al-Iqd al-manzūm fì dhikr afädil al-Rūm [as an annex to alShaqā’iq al-Nu'māniyya by Țāshkuprī-zāda] (Beirut: Dār al-Kitāb al'Arabī, 1975).

Āl al-Sheikh, Șāliḥ ibn 'Abd al-'Azīz ibn Muhammad ibn Ibrāhīm, al-La'ālī lbabiyya fì sharb al-'Aqīda al-Wāsitiyya, 2 vols., (ed. 'Ādil ibn Muhammad Mursī Rifā̄īi; Riyadh: Dār al-'Āṣima, 2010).

Arıc1, Mustakim, "İslâm Düşüncesinde Fahreddin er-Râzî Ekolü," in Ömer Türker and Osman Demir (eds.), Fahreddin Râzî (Istanbul: İSAM Yayınları, 2013), 167-202.

Arslan, Ahmet Turan, "İmam Birgivîye Nisbet Edilen Bazı Eserler," in İbrahim Gümüs (ed.), 1. Ulusal İslam Elyazmaları Sempozyumu (1314 Nisan 2007) Bildiriler Kitabı (Istanbul: Türkiye Çevre Koruma ve Yeşillendirme Kurumu [TÜRÇEK], 2009), 175-182.

Arslantürk, Ayşe Hümeyra, "Nesefî, Necmeddin," Türkiye Diyanet Vakfi İslâm Ansiklopedisi (DİA), XXXIII, 571-573.

'Āshiq Chalabī, Pīr Muḥammad ibn 'Alīibn Muḥammad, Mi'rāj al-'iyāla waminhāj al-cadāla (MS Istanbul: Süleymaniye Library, Şehid Ali Paşa, 1556).

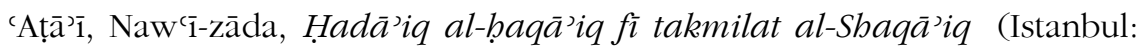
Çağrı Yayınları, 1989).

Bernand, Marie, "Le muhtașar fī bayān al-i'tiqād," Annales Islamologiques 18 (1982), 1-33.

Birgiwī, Muḥammad ibn Pīr 'Alī, Inqādh al-hālikīn in Aḥmad Hādī al-Qaș̣ār (ed.), Rasā’il al-Birgiwì (Beirut: Dār al-Kutub al-'Tlmiyya, 2011), 4981.

Birgiwī, Muḥammad ibn Pīr 'Alī, Ziyārat al-qubūr in Aḥmad Hādī al-Qașșār (ed.), Rasā’’il al-Birgiwī (Beirut: Dār al-Kutub al-'Ilmiyya, 2011), 153182.

Birgiwī, Muhammad ibn Pīr 'Alī, al-Ṭarīqa al-Muḩammadiyya wa-l-sīra alAḥmadiyya (ed. Muḥammad Ḥusnī Mușțafā; Aleppo: Dār al-Qalam al'Arabī, 2002).

Birgiwī, Muḥammad ibn Pīr 'Alī, Miḥakk al-ṣūfiyya (Istanbul: Maktabat Darsa‘̄àda, 1988).

Birgiwīi, Muḥammad ibn Pīr 'Alī [as Birgili Muhammed Efendi] Vasiyyetnâme: Dil İncelemesi, Metin, Sözlük, Ekler İndeksi ve Tipkıbasım (ed. Musa Duman; Istanbul: Risale Yayınları, 2000). 
Birgiwī, Muḥammad ibn Pīr 'Alī, Dāmighat al-mubtadi'īn (eds. 'Abd alRahīm al-Sāyiḥ and Tawfīq 'Alī Wahba; Cairo: Dār al-Āfāq al'Arabiyya, 2010).

Bruckmayr, Philipp, "The Particular Will (al-irādat al-juz’iyya): Excavations Regarding a Latecomer in Kalām Terminology on Human Agency and Its Position in Naqshbandi Discourse," European Journal of Turkish Studies [Online] 13 (2011), 2-20, available at http://ejts.revues.org/4601.

al-Bukhārī, 'Alā' al-Dīn, Fā dị̣at al-mulḅidīn, in Muhammad ibn Ibrāhīm al'Awḍī, Fādihat al-mulḅidinn wa-nāṣihat al-muwaḅhidìn (MA thesis; Mecca: Jāmicat Umm al-Qurā, 1414).

al-Būṭī, Muḥammad Sa'̄id Ramaḍān, al-Salafiyya: marhala zamaniyya mubāraka lā madhhab Islāmī (8 $8^{\text {th }}$ edn., Damascus: Dār al-Fikr, 2006).

Cook, Michael, Commanding Right and Forbidding Wrong in Islamic Thought (Cambridge: Cambridge University, 2004).

Currie, James Muhammad Dawud, "Kadizadeli Ottoman Scholarship, Muhammad ibn 'Abd al-Wahhāb, and the Rise of the Saudi State," Journal of Islamic Studies 26 (3), 2015, 265-288, http://dx.doi.org/10.1093/jis/etv083.

Çağrıc1, Mustafa, "Gazzâlî̀nin İhyâ'sı ile Birgivî'nin Tarîkat-1 Muhammediyye'sinin Mukayesesi”, İslâmî Araştırmalar (Gazzâlî Özel Sayısi) 13/3-4 (2000) 473-478.

al-Dihlawī, Farīd al-Dīn 'Ālim ibn al-'Alā' al-Indarapatī, al-Fatāwā lTātārkhāniyya, 23 vols., (ed. Shabbīr Ahmad al-Qāsimī; Deoband: Maktabat Zakariyyā', 2010).

Evstatiev, Simeon, “"The Qāḍizādeli Movement and the Revival of takfìr in the Ottoman Age," in Camilla Adang, Hassan Ansari, Maribel Fierro, and Sabine Schmidtke (eds.), Accusations of Unbelief in Islam: A Diachronic Perspective on Takfīr (Leiden \& Boston: Brill, 2015), 213243 , http://dx.doi.org/10.1163/9789004307834_010.

Fawrā, 'Alī Miṣrī Simjān, "Dirāsa" [Study on Majālis al-abrār by Aḥmad Rūmī (Aqhisārī)] (PhD dissertation; Medina: al-Jāmica al-Islāmiyya, 2007), 1-44.

al-Ghazālī, Abū Hāmid Muḥammad ibn Muḥammad ibn Muḥammad, Minhāj al-'ābidīn ilā jannat Rabb al-'ālamīn (ed. Maḥmūd Mușțafā Halāwī; Beirut: Mu’assasat al-Risāla, 1989).

Ibn al-Bazzāzī, Hāfiz al-Dīn Muḥammad ibn Muḥammad ibn Shihāb alKardarī al-Bazzāzī, al-Fatāwā l-Bazzāziyya [in the marginal note of al-Fatāwā l-Hindiyya fì madhbab al-Imām al-A`zam Abī Hañ̄fa alNu'mān], 6 vols., (Būlāq: al-Mațba‘a al-Kubrā al-Amīriyya, 1310). 
Ibn Faqīh, 'Abd al-Bāqī ibn 'Abd al-Bāqī Ibn Faqīh Fiș̣̦a al-Mawāhibī alHanbalī, al-'Ayn wa-l-athar fì 'aqā'id abl al-athar (ed. 'Ișām Rawwās Qal'ajīi; Damascus: Dār al-Ma’mūn li 1-Turāth, 1987).

Ibn al-Jawzī, Abū 1-Faraj 'Abdurrahmān ibn 'Alī, Talbīs Iblīs (ed. Sayyid alJumaylī; Beirut: Dāral-Kitāb al-'Arabī, 1994).

Ibn Qayyim al-Jawziyya, Abū 'Abd Allāh Shams al-Dīn Muhammad, Kitāb alșalāt (ed. 'Adnān ibn Ṣāāākhān al-Bukhārīi; Mecca: Dār al-'Ālam alFawā’id, 1431).

Ibn Taymiyya, Taqī al-Dīn Ahmad ibn 'Abd al-Halīm, Dar' ta'ārud al-'aql wa-l-naql, 11 vols., (ed. Muḥammad Rashād Sālim; $2^{\text {nd }}$ edn., Medina: Jāmi at al-Imām Muhammad ibn Sưūd al-Islāmiyya, 1991).

Ibn Taymiyya, Taqī al-Dīn Aḥmad ibn 'Abd al-Halīm, al-İmān (ed. Muḥammad al-Zubaydī; Beirut: Dār al-Kitāb al-'Arabī, 1993).

Ibn Taymiyya, Taqī al-Dīn Aḥmad ibn 'Abd al-Halīm, Iqtiḍà' al-șirāt almustaqìm li-mukhālafat așhāāb al-jahìm, 2 vols., (ed. Nāṣir 'Abd alKarīm al-'Aql; Riyadh: Maktabat al-Rushd, 1994).

Ibn Taymiyya, Taqī al-Dīn Aḥmad ibn 'Abd al-Halīm, Minhāj al-sunna alNabawiyya, 9 vols., (ed. Muhammad Rashād Sālim; Riyadh: Mu’assasat Qurțuba, 1986).

Ibn Taymiyya, Taqī al-Dīn Aḥmad ibn 'Abd al-Ḥalīm, Majmū' fatāwā, 37 vols., (ed. 'Abd al-Raḥmān ibn Muḥammad ibn Qāsim; Medina: Mujamma' al-Malik Fahd li-Ṭibā'at al-Mușhāâ al-Sharīf, 2004).

Ibn Taymiyya, Taqī al-Dīn Aḥmad ibn 'Abd al-Halīm, Siyâset: es-Siyâsetü'şŞeriyye (translated by Vecdi Akyüz; $2^{\text {nd }}$ edn., Istanbul: Dergâh Yayınları, 1999).

Ibn Taymiyya, Taqī al-Dīn Aḥmad ibn 'Abd al-Halīm, al-Tadmuriyya: Tahquiq al-ithbāt li-l-asmā' wa-l-sifät wa-haqīqat al-jam' bayna lqadar wa-l-shar' (ed. Muhammad ibn 'Awda al-Sa'wī; Riyadh: Maktabat al-'Ubaykān, 2000).

İzmirli, İsmail Hakkı, Yeni Ilm-i Kalām, 2 vols. in 1 vol., (Istanbul: Awqāf-i Islāmiyya Mațba'asi, 1339-1341).

al-Janābī, Abū Muhammad Muștafā ibn Husayn ibn Sinān, al-'Aylam alzākhir fì aḥwāl al-awa'̀il wa-l-awākhir [also known as Tārìkh alJanābi (MS Istanbul, Nuruosmaniye Library, no. 3100).

al-Jīlānī, Abū Muḥammad 'Abd al-Qādir ibn Abī Ṣāliḥ 'Abd Allāh, Sirr alasrār wa-mazhar al-anwār fì-mā yahtāju ilayhi l-abrār (eds. Khālid Muḥammad 'Adnān al-Zar'ī and Muḥammad Ghassān Naṣūḥ 'Azqūl; $4^{\text {th }}$ edn., Damascus: Dār al-Sanābil, 1995).

Kalayc1, Mehmet, Tarihsel Süreçte Eşarilik-Maturidilik İlişkisi (Ankara: Ankara Okulu Yayınları, 2013). 
Kara, İsmail, İlim Bilmez Tarih Hattrlamaz: Şerh ve Haşiye Meselesine Dair Birkaç Not (2 ${ }^{\text {nd }}$ edn., Istanbul: Dergâh Yayınları, 2013).

Kātib Chalabī, Hājīi Khalīfa Mușțafā ibn 'Abd Allāh [as Kâtip Çelebi], Mîzânü'l-Hakk fì ibtiyâri'l-ebakk [=Mīzān al-haqq fì ikbtiyār alahaqq] (translated into Turkish by Orhan Şaik Gökyay and Süleyman Uludağ; Istanbul: Kabalcı Yayınevi, 2008).

Kaylı, Ahmet, A Critical Study of Birgiwi Meḅmed Efendì's (d. 981/1573) Works and Their Dissemination in Manuscript Form (MA thesis; Istanbul: Boğaziçi University, 2010).

al-Khādimī, Abū Sa'̄̄e Muhammad ibn Mușțafā ibn 'Uthmān, al-Barīqa alMạ̣müdiyya fì sharh al-Ṭarqqa al-Muhammadiyya, 4 vols. in 2 vols., (Istanbul: Shirkat-i Șaḥāfiyya-i 'Uthmāniyya, 1316).

Krrbaşoğlu, Mehmet Hayri, "Maziden Atiye Selefî Düşüncenin Anatomisi," İslâmiyât (Kökencilik Özel Sayısı) 10/1 (2007), 139-160.

Koca, Ferhat, "Osmanlı Fakihlerinin Semâ, Raks ve Devrân Hakkındaki Tartışmaları," Tasavvuf: İmî ve Akademik Araştırma Dergisi 5/13 (2004), 25-74.

Kufrevî, Kasim, "Birgewī," in: Encyclopaedia of Islam Second Edition, (eds. P. Bearman, Th. Bianquis, C.E. Bosworth, E. van Donzel, and W.P. Heinrichs; accessed June 16, 2015), http://dx.doi.org/10.1163/15733912_islam_SIM_1434.

Lekesiz, Hulusi, XVI. Yüzyıl Osmanl Düzenindeki Değişimin Tasfiyeci (Püritanist) Bir Eleştirisi: Birgivî Mebmed Efendi ve Fikirleri (PhD dissertation; Ankara: Hacettepe University, 1997).

Lekesiz, Hulusi, "Osmanlı İlmi Zihniyeti: Teşekkülü, Gelişmesi ve Çözülmesi Üzerine Bir Tahlil Denemesi,” Türk Yurdu, 21/49 (1991), 20-32.

Mart1, Huriye, Birgili Mehmed Efendinin Hadisçiliği ve et-Tarîkatü'lMuhammadiyye: Tabkik ve Tablil (PhD dissertation; Konya: Selçuk University, 2005).

Mart1, Huriye, Birgivî Mebmet Efendi: Hayatı, Eserleri ve Fikir Dünyası (Ankara: Türkiye Diyanet Vakfı Yayınları, 2008).

Martı, Huriye, Birgivî Mehmed Efendi: Osmanlı'da Bir Dâru'l-Hadis Şeyhi (Istanbul: Dârulhadis, 2008).

Mart1, Huriye, "Tarîkat-1 Muhammediyye," Türkiye Diyanet Vakfi İslam Ansiklopedisi (DİA), XL, 106-108.

Michot, Yahya, introduction to Against Smoking: An Ottoman Manifesto, by Aḥmad al-Rūmī al-Āqhișārī (ed. and translated by Yahya Michot; Leicestershire: Interface Publications \& Kube Publishing, 2010), 1-44.

al-Nasafī, Najm al-Dīn Abū Hafs 'Umar, Risāla fì bayān madhāhib altaṣawwuf in Muhammad ibn al-Hasan al-Hurr al-'Āmilī, Risālat al- 
ithnay 'ashariyya fì l-radd 'alā l-ṣüfiyya (ed. Muhammad ibn alHasan al-Tafrishī al-Darūdī; Qom: al-Mațba'a al-'Ilmiyya, 1400) 23-25, available at http://www.alhawzaonline.com/almaktaba-almakroaa/ book/238-aqa'ed/0334-al\%20ethna\%203asharia/01.htm （accessed October 3, 2009).

al-Nasafī, Najm al-Dīn Abū Hafs 'Umar, "Kitâb fî̀ Mezâhibi'l-Mutasavvifa [Kitāb fī madhāhib al-mutașawwifa]" (translated by Süleyman Uludağ), Diyanet Dergisi, 18/3 (1979) 167-173.

Ocak, Ahmet Yaşar, Yeniçă̆lar Anadolu'sunda İslam'in Ayak İzleri: Osmanh Dönemi, Makaleler-Araştırmalar (Istanbul: Kitap Yayınevi, 2011).

Ocak, Ahmet Yaşar, "Religious Secience and Ulema," in Halil İnalcık and Günsel Renda (eds.), Ottoman Civilization (translated by Ellen Yazar and Priscilla Mary Işın; Ankara: Ministry of Culture, 2003), I, 243-265.

Ocak, Ahmet Yaşar, "al-Ḥayāt al-dīniyya wa-l-fikriyya," in Ekmeleddin İhsanoğlu (ed.) al-Dawla al-'Uthmāniyya: tārīkh wa-ḥadāra, 2 vols.,

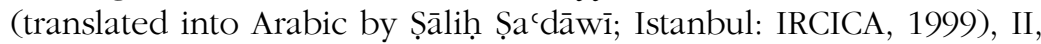
153-298.

Ocak, Ahmet Yaşar, "Ottoman Intellectual Life in the Classical Period," in H. C. Güzel, K. Çiçek, and S. Koca (eds.), The Turks, 3 vols., (Ankara: Yeni Türkiye Publications, 2002), III, 743-755.

Ocak, Ahmet Yaşar, "İbn Kemâl'in Yaşadığı XV ve XVI. Asırlar Türkiye'sinde İlim ve Fikir Hayatı," in S. Hayri Bolay, Bahaeddin Yediyıldız, and. M. Sait Yazıcıoğlu (eds.), Tokat Valiliği Şeybülislam İbn Kemâl Araştırma Merkezi'nin Tertip Ettiği Şeybülislâm ibn Kemâl Sempozyumu: Tebliğler ve Tartısmalar ( $2^{\text {nd }}$ edn., Ankara: Türkiye Diyanet Vakfi, 1989), 29-36.

al-Qushayrī, Abū 1-Qāsim Zayn al-Islām 'Abd al-Karīm ibn Hawāzin, alRisāla al-Qushayriyya, 2 vols., (eds. 'Abd al-Halīm Mahmūd and Maḥmūd ibn al-Sharīf; Cairo: Dār al-Ma‘ārif, n.d.).

Öngören, Reşat, "Osmanlılar Döneminde Semâ ve Devran Tartışmaları," Tasavvuf: Ilmî ve Akademik Araştırma Dergisi 11/25 (2010), 123-132.

Özcan, Tahsin, Osmanlı Para Vakıfları: Kanûnî Dönemi Üsküdar Örneği (Ankara: Türk Tarih Kurumu, 2003).

Qāḍī-zāda Aḥmad [as Kadızâde Ahmed], Birgivî Vasiyetnâmesi: Kadızâde Şerbi (simplified by A. Faruk Meyan; Istanbul: Bedir Yayınları, 2009).

Qāọī-zāda Meḥmed [Muḥammad ibn Mușțafā ibn Muḥammad], Tāj al-rasā'il wa-minhāj al-was $\bar{a}^{\prime} i l$ (MS Istanbul: Süleymaniye Library, Hac1 Mahmut Efendi, no: 1926). 
al-Rāzī, Abū 'Abd Allāh Fakhr al-Dīn Muhammad ibn 'Umar, Munāzarāt Fakhr al-Dīn al-Rāzī fì bilād Māwarā' al-nahr (ed. Fatḥ Allāh Khulayf; Beirut: Dār al-Mashriq, 1966).

El-Rouayheb, Khaled, Islamic Intellectual History in the Seventeenth Century: Scholarly Currents in the Ottoman Empire and the Maghreb (New York: Cambridge University Press, 2015).

El-Rouayheb, Khaled, "From Ibn Hajar al-Haytamī (d. 1566) to Khayr al-Dīn al-Ālūsī (d. 1899): Changing Views of Ibn Taymiyya among NonHanbali Sunni Scholars," in Yossef Rapoport and Shahab Ahmed (eds.), Ibn Taymiyya and His Times (Karachi: Oxford University Press, 2010), 269-318.

El-Rouayheb, Khaled, "The Myth of 'The Triumph of Fanaticism' in the Seventeenth-Century Ottoman Empire," Die Welt des Islams 48/2 (2008), 196-221, http://dx.doi.org/10.1163/157006008X335930.

al-Ṣaffār, Abū Isḥāq Ibrāhīm al-Bukhārī, Talkhịṣ al-adilla li-qawā'id altawhid, 2 vols., (ed. Angelika Brodersen; Beirut: Orient Institut, 2011).

al-Saffārīnī, Abū l-'Awn Shams al-Dīn Muhammad ibn Aḥmad ibn Sālim alHanbalī, Lawāmic al-anwār al-babiyya wa-sawātị al-asrār alathariyya li-sharh al-Durra al-mudiyya fi caqd al-firqa al-mardiyya, 2 vols., ( $2^{\text {nd }}$ edn., Damascus: Mu’assasat al-Khāfiqīn wa-Maktabatuhā, 1982).

Sayyid 'Alī-zāda, Mafātīḥ al-jinān: Sharh Shir'at al-Islām (Istanbul: alMațba'a al-'Uthmāniyya, 1317).

al-Sharīf, Fuhayd ibn Manșūr ibn Zāmil ibn Lu’ayy, introduction to Aḥwāl atfāl al-muslimìn, by Birgiwī (MA thesis; Mecca: Jāmi`at Umm alQurā,1434).

Sheikh, Mustapha, "Taymiyyan Influences in an Ottoman-Hanafī Milieu: The Case of Aḥmad al-Rūmī al-Āqhịsārī," Journal of the Royal Asiatic Society 25/1 (2015), 1-20.

Ṭarīqatchī Amīr Mușțafā, Farā’id al-'aqā’id al-bahiyya fì ḥall mushkilāt alTarīqa al-Muhammadiyya (MS Istanbul: Nuruosmaniye Library, no: 2318)

al-Taftāzānī, Sa'd al-Dīn Mas'ūd ibn 'Umar ibn 'Abd Allāh, Sharḥ alMaqāṣid, 5 vols., (ed. 'Abd al-Raḥmān 'Umayra; $2^{\text {nd }}$ edn., Beirut: 'Ālam al-Kutub, 1998)

al-Taftāzānī, Sa'd al-Dīn Mas'ūd ibn 'Umar ibn 'Abd Allāh, Sharh al-Talwīh 'alā l-Tawdīh li-matn al-Tanqīh fì ușūl al-fiqh, 2 vols., (ed. Zakariyyā 'Umayrāt; Beirut: Dār al-Kutub al-'Tlmiyya, 1996) 
Terzioğlu, Derin, Sufi and Dissident in the Ottoman Empire: Niyāzīi i Mișrì, 1618-1694 (PhD dissertation; Cambridge, MA: Harvard University, 1999).

Terzioğlu, Derin, "Bir Tercüme ve Bir İntihal Vakası: Ya da İbn Teymiyye'nin Siyāsetü'ş-Şer'iyye'sini Osmanlıcaya Kim(ler), Nasıl Aktardı?” Journal of Turkish Studies: Türklük Bilgisi Araşttrmaları 31/2 (2007), 247-275.

Terzioğlu, Derin, "Sunna-minded sufi preachers in service of the ottoman state: the nașinatnāme of Hasan addressed to Murad IV," Archivum Ottomanicum 27(2010), 241-312.

Unan, Fahri "Dinde Tasfiyecilik Yahut Osmanlı Sünnîliğine Sünnî Muhâlefet: Birgivî Mehmed Efendi," Türk Yurdu 36/382 (1990), 33-43.

al-'Urābī, Sultānn ibn 'Ubayd ibn 'Abd Allāh, Dāmighat al-mubtadi'ìn wakāshifat buṭlān al-mulḅidīn: Imām Muḅammad ibn Pìr 'Alī ibn Iskandar al-Birgiwī - Dirāsa wa taḥqūq - min awwal al-kitāb ilā qawlihī "wa-ammā thawāb al-camal bi-l-sunna" (MA thesis; Mecca: Jāmi'at Umm al-Qurā, n.d.).

al-'Uthaymīn, Muḥammad Șāliḥ, Sharh al-Wāsitịyya li-Sheikh al-islām Ibn Taymiyya (ed. Sa`d ibn Fawwāz al-Ṣumayl; $6^{\text {th }}$ edn., Riyadh: Dār Ibn al-Jawzī, 2000).

Wadādī (Widādī), Takmila-i tarjama-i Ṭariqat-i Muhammadiyya (Istanbul: Dār al-Salțana, 1256).

Yllmaz, Hüseyin, The Sultan and the Sultanate: Envisioning Rulership in the Age of Süleymān the Lawgiver (1520-1566) (PhD dissertation; Ann Arbor: Harvard University, 2005).

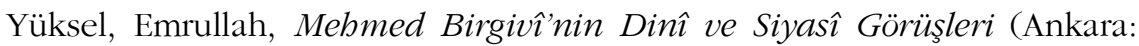
Türkiye Diyanet Vakfı Yayınları, 2011).

Yüksel, Emrullah, "Mehmed Birgivî," Atatürk Üniversitesi İslâmî İlimler Fakültesi Dergisi 2 (1977), 175-185.

al-Zabīdī, Abū l-Fayḍ Muḥammad al-Murtaḍā ibn Muḥammad, Itḥāf al-sāda al-muttaqìn bi-sharh I I̧yā ulüm al-dīn, 14 vols., (3 ${ }^{\text {rd }}$ edn., Beirut: Dār al-Kutub al-'Tlmiyya, 2002).

Zilfi, Madeline C., The Politics of Piety: the Ottoman Ulema in the Postclassical Age: 1600-1800 (Minneapolis: Bibliotheca Islamica, 1988). 